\title{
Devaneio e Crítica Preliminares ao Papel da Fantasia na Paisagem
}

Eduardo Yázigi

Professor livre-docente junto ao Departamento de Geografia da USP. Atualmente desenvolve pesquisa sob patrocínio do CNPq, sobre $A$ alma do Iugar, onde focaliza a questão da identidade espacial dos lugares em vista do planejamento, face à globalização. Este ensaio corresponde a

um de seus enfoques

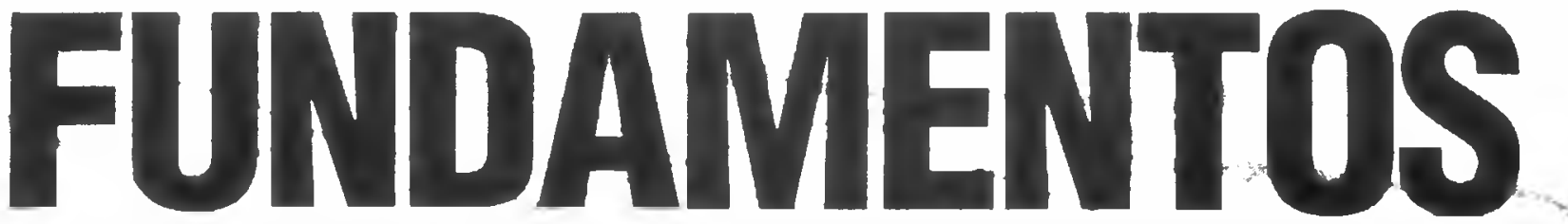


Desde longo tempo, a literatura especializada vem explorando o papel da percepção no entendimento da paisagem, sem contudo situar o peso da fantasia em seu contexto. Ela é aqui entendida como importante ingrediente do psiquismo, nas autorepresentações e nas representações cósmicas. Freqüentemente, fantasia e espetáculo são criticados, mas os autores costumam se esquecer que quando alguem faz uma casa ou jardim, ou quando se é turista, o psiquismo não pode ser separado das condições gerais da vida mental. Nesta ordem de idéias, este ensaio pretende ser uma introdução à relação entre as esferas pública e privada, a fim de subsidiar o planejamento urbano e regional.

During a long while, perception has been explored as an important part of landscape meaning, but fantasy looks not enough explored. Here it is first understood as an important ingredient of psychism - the auto representation and the cosmic representation. Very often fantasy and spectacle are criticized, but authors also forget that when someone builts a house, a garden or when he is a tourist, psychism cannot be separated from general conditons of mental life. In any case, this approach tries to be an introduction to the relation between public and private spheres, in order to help on town and country planning. 


\section{Devaneio e Crítica Preliminares ao Papel da Fantasia na Paisagem}

Panen at circensis

Juvenal século 2 d.C.

$\mathrm{F}$ antasia e espetáculo já contam com vasta literatura, mas uma simples busca bibliográfica nas redes informatizadas, mostrará que seus cruzamentos com paisagem ou, mais especificamente, planejamento do turismo, resulta em bem pouco. Entenda-se, também, que o planejamento espacial do turismo só pode ser concebido como planejamento ou desenvolvimento urbano e regional tout court, o que torna o assunto mais insólito ainda... Ao pensar a alma do lugar, não via como furtar-me ao sentido da poesia no espaço, campo que tem muito a ver com o caráter da arquitetura, do urbanismo e do paisagismo em geral. Daí o estranhamento de se lidar com a fantasia nessas áreas. Devo pois admitir a delicadeza do tema proposto - um assunto que tem de ser enfrentado na justa medida. A meu ver, a crítica procedente, que o espetáculo tem recebido enquanto estratégia do consumismo inibe um certo sentido legítimo das exteriorizaçōes da funçāo e que, negando tudo, elimina o sal da terra. Terra que, por acaso ou não, é naturalmente repleta de espetáculos até em suas regiões mais áridas; cenas movediças a cada momento de luz, a cada estação do ano. Terra que, com a mão do homem, não deveria perder uma certa visão maravilhosa, gratuitamente experimentada por milhares de gerações.

Cotidiano e turismo mesclam-se no mesmo lugar. Como em maior ou menor grau, ambos se povoam de espetáculo e fantasias que se exteriorizam na organização do território, pareceu-me prudente, antes de mais nada, explorar esses ingredientes no contexto da própria vida. Para fins deste estudo, trata-se apenas de buscar as implicações de espetáculo e fantasia no território, sem contudo perder de vista a complexidade em que ocorrem. 
Pão e circo - é só isso que o povo quer do Forum, dizia o latino Juvenal em suas Sátiras. O que muda, quase dois milênios mais tarde? Este capítulo, especificamente, guarda certo caráter de ensaio, já que consiste num esforço preliminar de relacionar representações e psiquismo com políticas territoriais.

Não se trata de discussão gratuita. Imaginar e imprimir diretrizes de uso e ocupação do solo; código de obras ou práticas do planejamento como processo, especialmente para lugares turísticos, pressupõe resolver o sentido a ser dado à paisagem. Um sentido voluntarista, mas apoiado em fundamentos psicológicos e filosóficos. Aqui se misturam preconceitos e divergências, entre crítica acadêmica e usuários: gosto, forma e consumo são questões universalmente polêmicas. Trarei meu ponto de vista, na esperança que sua abordagem dialética sirva para mostrar os reveses da questão e, mais que isso, possa situar parâmetros e proporcionar reconsiderações em vista do manejo do território. O tema é ambíguo, contraditório, mas tem de ser iniciado.

Está na hora de se falar sobre fantasia \& espaço. Nem toda fantasia é exteriorizada lato sensu, mas quando ocorre impregna o meio: na arquitetura e seus adornos; em variada gama de símbolos; nos mais diversos arranjos da natureza; na animação e nas próprias relações dos homens entre si e com seus meios. O espaço reflete fantasias pessoais que realizam auto-representações e representações cósmicas. E também, ao contrário do que se tem vulgarizado, nem toda fantasia é feita para ser vendida ou é propriamente nociva. São evidências que merecerão consideraçōes mais aprofundadas no decorrer deste enfoque pelos caminhos do devaneio.

\section{U ma velha preocupação}

Afirma-se que o próprio homem de Neanderthal já se servia da imaginação. Fiquemos com os gregos, que denominavam empiria a mais ampla forma de saber, composta da percepção sensível, da imaginação e da memória, mas formando uma unidade inseparável. Aristóteles, em seu tratado Sobre a Alma, já no século 4 a.C. filosofava sobre a existência da fantásmata (plural de fántasma) ou fantasias, entre as quais distinguia o fántasmata esthetikón (fantasma sensorial ou estética); o

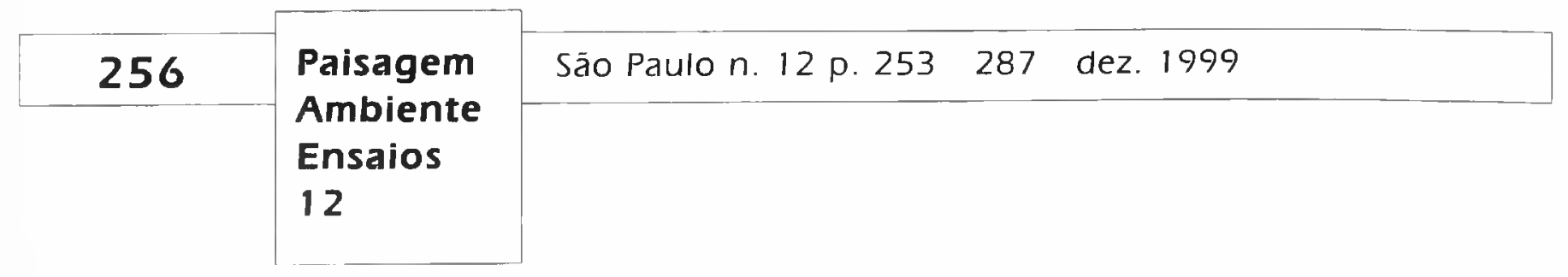


loguistiké e o boulitiké, respectivamente calculador e deliberativo. Entendia a fantasia como atividade e o fantasma como produto. Distinguia imaginação de sensação: L'imagination, en effet, est quelque chose de distinct à la fois de la sensation et de la pensée, bien qu'elle ne puisse exister sans la sensation, et que, sans elle, il n'y ait pas non plus de croyance (Aristóteles: 165); usa ainda a bela imagem, dizendo que a imaginação (fantasia) tira seu nome de "luz" (Idem: 172), em grego. A capacidade de imaginar seria a essência da condição humana. Mas Aristóteles não se refere à fantasia criadora (que cria o não existente no mundol, mas ao que Kant chamou de fantasia reprodutora, uma modificação da fantasia originária (Szilasi: 69).

Ricardo Malfé grifa a forma loguistiké de fantasiar como uma antecipação do provável: la imaginación lque es 10 mismo que decir "fantasia" en las lenguas derivadas del latín/ calcula lo que podría acaecer a partir de una experiencia previa, de la que extrae pautas de verosimilitud (p.13). Segundo interpretação deste mesmo autor, tanto Aristóteles como Platão, ainda que em tempos distintos, reconhecem que a trama da fantasia, no sonho ou na vigília, urde-se por pressão do desejo (órexis). (Arthur Schopenhauer consagra uma grande obra em três volumes acentuando o enorme papel do desejo nos processos mentais.) São Tomás de Aquino (século 13, autor da Suma teológica), por seu turno, vê a imaginação ou fantasia (que são a mesma coisa) como potências ativas. Por isso Wilhelm Szilasi (p. 77) comenta que La sofía realiza la mediación entre la fantasía transcedental y el conocimiento científico, ligado a las cosas.

Espetáculo e festa tornaram-se o leitmotif do turismo. Um alimenta o outro. Enquanto, de um lado há cada vez mais público nessas sendas, por outro, a crítica permanece inclemente quanto a seus significados. A fantasia sempre povoou o espírito dos homens. Mas agora, industrializada, ela invade todos os momentos e todos os recantos da existência ao serviço do mercado e do poder... Quando o 'meio ambiente' como natureza-espetáculo, substitui a natureza-histórica, lugar de trabalho de todos os homens, e quando a natureza 'cibernética' ou 'sintética substitui a natureza analítica do passado, o processo de ocultação atinge seu auge - afirma sabiamente Milton Santos (1994: 23-24). Eis a questão.

É difícil não concordar com Milton Santos, que representa uma plêiade de autores com o mesmo pensamento. Ulpiano Toledo Bezerra de 
Meneses (1995: 98) questiona até o valor dos denominados "patrimônios da humanidade" declarados pela Unesco, na medida em que se tornam objetos de voyerismo. Minha proposta, agora, é entender o outro lado das produçōes do mercado, isto é, a do homem comum, sequioso de deleites. Pergunto-me se o mercado procede assim por que quer, ou por que desejam que assim seja. É como a história de quem nasceu primeiro, o ovo ou a galinha. Mais ainda, quisera saber se uma possível reversão da questão não implicaria muito mais numa vigorosa cobrança do espectador-consumidor.

Desde o clássico Fantasma da liberdade, de Luis Buñuel, venho indagando sobre o sentido de nossa vida cotidiana. Bem no início do filme, ele mostra um senhor e uma criança sentados no banco público de um parque, onde o mais velho exibe cartões postais ao jovem. Fica sugerido que ambos estão a se deliciar com cada imagem que passa. Todavia, focalizando os próprios cartões, vêem-se aranhas, serpentes, figuras escabrosas... Aliás, a película inteira nada mais é do que uma brincadeira em torno das inversões, deixando supor que a liberdade seja um fantasma a nos perseguir, na medida em que, simplesmente virando as imagens pelo avesso, o resultado poderá ser tão esdrúxulo quanto o modelo original.

Para Otávio de Souza a fantasia é o meio pelo qual o homem constrói determinados padrões de gozo e estabelece caminhos e estratégias para atingi-los. Não sem razão, fantasia (sonhos, devaneios) são cantados por poetas. Gaston Bachelard (p. 17) deu à uma grande obra sua, o título $O$ direito de sonhar, dizendo hay que soñar mucho: soñar cobrando conciencia de que la vida es sueño... Frederico Garcia Lorca não fica por menos: Hay que soñar. Desdichado el que no sueña, nunca verá la luz... (Impresiones y Paisajes, 809: 810). Baudelaire também dizia: é preciso embebedar-se sempre - de vinho, de poesia, de virtude, como lhe aprouver... Nessas trilhas, o devaneio teria de ser um contraponto em nossas vidas, em oposição à realidade banal.

\section{A Iguns aportes da psicologia}

A necessidade de análise (isto é, separação das partes do objeto) faz parte da investigação científica, tanto quanto a síntese (rearticulação) - 
raramente praticada. Resulta que esse comportamento repetido em cada disciplina, acaba por fragmentar a composição da realidade viva: muitos cruzamentos não são buscados entre diferentes campos, como se cada um tivesse uma autonomia superior, uma dinâmica não sujeita a outras influências. As associações aqui buscadas, são uma tentativa de explicaçāo da relação de certas fantasias com o espaço vivido.

Uma distinção se impõe de imediato, para os fins deste enfoque: a fantasia produto da imaginação pessoal e a chamada fantasia culturalmente partilhada, emprestada. Ambas possuem importante papel no desenvolvimento da personalidade e de seu equilíbrio; na organização do futuro e nas trocas sociais. O mundo do cotidiano, como o olhar turista, são arquipovoados de fantasias e espetáculos. Mas como conclui Ethel S. Person (p. 312), supervisora do Centro de Treinamento Psicanalítico de Columbia University, e professora de psiquiatria clínica, a fantasia é para a evolução cultural o que a mutação é para a evolução biológica, e mutaçōes culturais, como mutaçōes biológicas, podem nos beneficiar, mas também podem nos matar. Lamenta que enquanto a criaçāo artística ou científica são reverenciadas, a fantasia e o fantasiar, que são outras espécies de imaginação, não raro se conotam negativamente. O preconceito seria uma forma de valorizar o trabalho em oposição ao mergulho do devaneio.

Mais uma vez o velho Freud (a: 173 sqq) explica: os desejos insatisfeitos são a força que atua por trás das fantasias... A pessoa feliz não sonha. Para ele, as fantasias transformadas em arte mascaram desejos infantis não realizados; são formas de defesa contra o reconhecimento direto desses desejos. Afirma que o devaneio tem similaridade com o sonho noturno, porque os dois se nutrem de desejos situados no inconsciente e ambos são veículos para realização dos mesmos (Freud, b: 148|. O fantasiar é um ato no qual o fantasista está consciente de pertencer à imaginação. O que o fantasiador faz é dirigir um script senão pertenceria ao domínio da alucinação ou da ilusão. Do mesmo modo, Freud relacionou a fantasia com os jogos infantis, ambos originários das mesmas motivações. Mas para ele, a função desses últimos, além de repetir o passado (controle de trauma) serviria antes para alívios emocionais e planejamento de adaptações do futuro. A fantasia pode tornar-se realidade. Este pensamento psicanalítico tende a dominar ainda hoje. A interpretação é complementada por Rapaport, para quem todos processos mentais, entre os quais a fantasia, constituem satisfaçōes parciais, com pequeno uso de energia que reduzem parcial- 
mente o impulso e permitem adiamento da grande descarga motora: é a teoria da catarse com uso da fantasia nas crianças e do devaneio nos adultos. Ela ajuda no resguardo da progressão da angústia.

Por essas razões, Ethel S. Person (p. 19), lembrando que a fantasia, não sendo atributo exclusivo do neurótico, permeia todas nossas escolhas e padrōes de comportamento; deve ser compreendida como uma das melhores formas de adaptação: ela cria um ambiente de esperança e forças para a resistência. Em seu livro $O$ poder da fantasia, ela chega a analisar as fantasias culturalmente compartilhadas, sem contudo, enveredar pelo caminho do espaço. Ou melhor, chega a falar em ícones, como navios que transportam nossos sonhos. A fantasia culturalmente organizada não nos atinge apenas passivamente, por meio de nossas familias e de mitos culturais gerais, mas também por nossa ativa exploração de materiais culturais. Cada um de nós processa a matéria-prima cultural para ver o que pode ser emendado para o script de nossos desejos e necessidades e de nossas fantasias subconscientes e inconscientes (p. 251). É o que muitos autores denominam, tanto na fantasia como na arte, caminho de duas mãos: o fluxo de informações vai e vem entre nós e o mundo. Emprestamos materiais da fantasia externa para os enredos individuais. Mas o que pedimos emprestado não fica para sempre no terreno da fantasia e pode afetar o mundo real... A fantasia culturalmente transmitida na forma de fantasia de empréstimo lança mãos de complexa mistura de arte e vida real, de experiência vivida ou delegada, toda mobilizada pelo comando de nossos preexistentes desejos, impulsos e fantasias inconscientes (p. 252-253). Em duas palavras, as fantasias compartilhadas ou de empréstimo teriam importante função na socialização do grupo: Ethel S. Person dá o nome de inconsciente cultural ao conjunto dos mitos de uma cultura particular.

Para outros autores, inclusive Freud, a imaginação conteria veios mágicos. Ela surge então como expressão da esperança, como intenção de transformar o mundo (Stort: 51 ) ... afinal, é uma denúncia do absurdo da situação vivida que, tornando impossível o ato criador, reduz o homem à impotência e solicita-/he a criação da magia... Da mesma forma, a imaginação é, em si mesma, mágica. Ouando imaginamos, nomeamos nossos desejos, ultrapassando o círculo fechado em que a realidade aprisiona-nos, impelidos que somos pelas aspiraçóes mágicas que controlam a dinâmica da nossa consciência. (Idem: 52).

\begin{tabular}{|l|l|lll|}
\hline 260 & $\begin{array}{l}\text { Paisagem } \\
\text { Ambiente } \\
\text { Ensaios } \\
12\end{array}$ & Sào Paulo n. 12 p. $253 \quad 287$ dez. 1999 \\
\cline { 3 - 4 } & & & \\
\end{tabular}


Eliana Stort (p. 48), sistematiza o imaginário como um amálgama de sonho e realidade. Nele o sonho é contado como se fosse realidade e a realidade como se fosse sonho. A imaginação seria uma fusão de três partes: a) uma paisagem fantástica, criada a partir de elementos conhecidos e que permite ultrapassá-los; bl uma paisagem real, aquela em que se vive, em que se enraiza e que está sempre mais ou menos presente, subjacente, mesmo que de forma não consciente; e, d) uma paisagem afetiva, sendo ela quase sempre um lugar da infância. Este lugar aparece idealizado, mítico, sob o enfoque dos sentimentos, das lembranças, das experiências de um adulto, deformado, se necessário, transmutado e povoado com os seres com quem convivemos e que amamos, no correr dos anos.

Por pertencer ao domínio da imaginação, o fantasiar, o faz-de-conta dos jogos, situa-se na base do pensamento criativo. Sugerido por Bergson que estudou as formas do rir lo humor é a capacidade de percepção da mesma coisa em duas matrizes de lógicas distintas), Arthur Koestler, W. I. B. Beveridge e Edward De Bonno, entre outros grandes teóricos da heurística, chamam a atenção para a importância do faz-de-conta (ou pensamento lateral, ou pensamento se/vagem) para o ato criativo, seja ele nas artes como nas ciências. É assim que muitos aspectos externos de excitação da imaginação, dependendo do uso feito pelo observador, podem se apresentar como de fina utilidade e não como vilōes: a imaginação é o mais poderoso utensílio đa ađaptação da espécie humana. Mas o uso da imaginação não é sem limites. Edgard Morin (p. 188) reconhece seu poder criador, desde que regulado pela competência lógica, pois sem amarras é fácil partir-se à ilusão ou ao delírio.

Por suas funções ligadas ao alter ego e à criatividade na vida em geral, vários psicólogos são de opinião que a ausência de fantasia seria tão danosa quanto seu excesso. Ademais, é preciso que se entenda a fantasia inclusive como identidade...

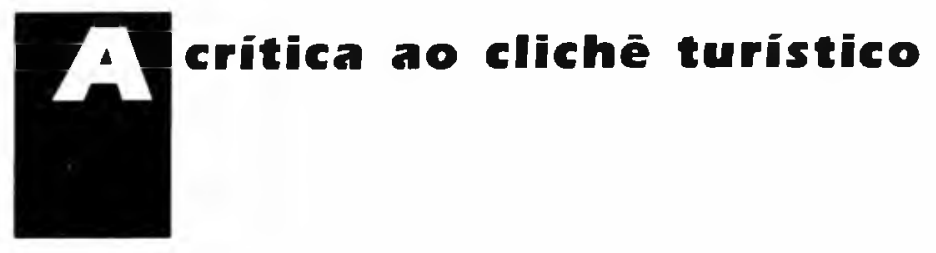

Os clichês, alimentadores de fantasias, vêm sendo criticados mais do que nunca. Comumente, significam um destaque separado da realida- 
de mais ampla - de Salvador só mostram o Pelourinho, igrejas, alguma praia... O entorno, indigno de ser visto, é intencionalmente escondido. É o caso em que, isolado do contexto, o bem cultural é convertido em apelo à irrealidade, com significado autônomo e, portanto, de significado menor. Seria possível fabricar posters de turismo de outro jeito? Poderíamos instar pessoas a visitarem o outro lado do espelho de Alice? Poderíamos dizer assim: Já que você vem ao Rio de Janeiro, aproveite para conviver nas favelas, nos antros de crime, droga e prostituição, não muito longe das praias...? Por isto, John Urry comenta (1996: 24), que o turismo se organiza em bolhas, o que permite a muitas pessoas visitarem lugares que, de outra maneira, não visitariam, e estabelecerem pelo menos algum contacto com os lugares 'estranhos que ali encontrarão.

O devaneio faz parte da excitação turística e por isto é sabiamente manipulado por seus agentes. Com outras palavras, é a "autenticidade encenada" Entretanto, como raríssimos brasileiros nāo assistem televisão, desafio que a menor das comunidades ignore a existência do mundo maldito, por mais que a propaganda turística tente dissimular. Numa outra possibilidade, própria de países centrais, é mais comum que todo um conjunto seja caprichosamente oferecido ao turismo. Paris (ou quase a França inteira...) é o clímax disso, em todos seus poros, ainda que não isenta de alguma crítica, por parte dos bastiões menos indulgentes. Ela é universalmente buscada: não por acaso, o país vem batendo recordes mundiais de turismo, com mais de sessenta milhões de visitantes/ano. Paris, Meca do espetáculo e da festa eterna...

Umberto Eco (p. 213-217) fala da malícia e ambigüidade que estabeleceu o rótulo "cultura como espetáculo" como se o teatro, a festa ou a banda não fossem cultura. Mas como, mesmo após décadas de antropologia cultural lque nos ensinou que até as posiçōes defecatórias fazem parte da cultura material de uma comunidadel, somos inclinados a falar em cultura apenas nos casos de cultura 'elevada' (literatura culta, filosofia, música clássica, arte de galeria e teatro de palcol, falandose de cultura como espetáculo, pretendia-se dizer algo bastante preciso... Em outros termos, parte-se do pressuposto de que espetáculo é divertimento, levemente culpado, ao passo que uma conferência, uma sinfonia de Bethoven, uma discussão filosófica, são experiências aborrecidas le portanto 'sérias'). Comenta que quando ele mesmo fazia uma palestra numa localidade qualquer, as pessoas não vinham tanto para ouvilo, como para tomar parte de uma manifestação coletiva. E não me 
digam que as pessoas se apinhavam nos teatros de Atenas para assistir a uma trilogia e a um drama satírico só para ficarem quietinhas até o fim. lam para lá viver um evento onde a presença dos outros também contava, $e$ as bancas com as comidas $e$ as bebidas, $e$ o rito em sua complexidade de festival 'cultural'... a espetacularização não significa necessariamente perda de intensidade, desatenção, leviandade. Tratase apenas de uma forma diferente de viver um debate cultural. Seja talvez por isto que Guy Debord (p.10) admite que o espetáculo se apresenta concomitantemente à sociedade, como parte sua, e como instrumento de unificação. A origem do espetáculo seria a perda da unidade do mundo e hoje, mais ainda.

Referindo-se a Campbell, Mike Featherstone (1995: 44) defende que o consumo capitalista precisa de uma ética, sendo que neste caso é seu romantismo e não o protestantismo que fornece tal estímulo, pois ele enfoca a imaginação, a fantasia, o misticismo, a criatividade e a exploração emocional. Daí que o prazer obtido pelas artes, modas, mídias, etc. não seria o resultado da manipulação dos empreendedores, mas uma "obsessão pelo status social" um gozo ilusório proporcionado pela fantasia. Jean Baudrillard tem idéias semelhantes, mas de outro contexto, quando fala da lógica e da estratégia do sistema de objetos, onde se estabelece cumplicidade entre investimentos psicológicos e imperativos sociais de prestígio. O turismo sempre se serviu secularmente do espetáculo e do devaneio: Baths na Inglaterra, Nice na França, e muitos outros lugares. Vista panorâmica e Be/vedere são conceitos e práticas já velhos. Foi na própria Antigüidade que se listaram as sete maravilhas do mundo.

O Clube Méditerranée da ilha de Itaparica, Bahia, é um exemplo gritante e consciente de fantasia, abstraído que está do espaço regional. Quem vai para lá, fica no Méditerranée e não na Bahia, convertido em bolha, onde coexistem recepcionistas polinesicamente enfeitados, cursos de pintura em seda, shows holiudianos, concertos de música clássica em meio a um bosque de coqueiros, ausência deliberada de relógios, num village que está mais para o Taiti do que qualquer parte das Américas. Quando lá passei, insinuei ironicamente a um turista de classe média que, efetivamente, ele não estava conhecendo a Bahia. Ao que me respondeu irritado: Mas quem disse que eu quero ver a Bahia? Numa outra ocasião, quando demonstrei inflexibilidade no uso de fantasias, ouvi isso de uma senhora comum: Quer saber de uma coisa? Acho você um grande desmancha-prazer!... Seguramente por uma ra- 
zão semelhante a esta, Ethel S. Person declara que o devaneio (daydreaming | nos libera do tédio da vida diária, das restrições de tempo e lugar, da armadilha do presente estupidificante... (p. 61)... a fantasia postula um amanhã melhor (p. 63).

As famosas feiras internacionais (da indústria ou outra coisa), tão em moda, produzem coleçōes de "ambientes típicos" com comida, bebida, arte, artesanato, livros, dança, trajes, artesanato, indústria, fotos, filmes, folhetos, vídeos, etc. Recriações ou pseudo-acontecimentos, onde num único dia e recinto, um cidadão comum acaba conhecendo mais coisas sobre o mundo do que em toda sua vida... A publicidade é essencialmente um faz-de-conta. Joga superficialmente com signos, descontextualizados da tradição ou da ordenação subcultural, e as pessoas deliciam-se com o fato de que tais signos são artificiais e opacos $e$ 'sem profundidade' no sentido de que não podem ser decodificados de forma e dar acesso a qualquer significado revelador ou a uma noção de verdade fundamental (Featherstone, 1995 a: 141). Sim, tudo fora de seu contexto, como também o são as boas exposições de ícones bizantinos no Grand Palais de Paris ou recitais de música sacra nas melhores salas de Nova York. Nada tem o quilate de uma experiência vivida, mas onde isso seria possível, senão no cotidiano das culturas? Como fica o possível conflito com uma cultura exótica? Atualmente, esse repertório de recriações de frentes de lucro e trabalho está na ordem do dia de várias cidades. Só de festivais, a França conta com mais de 400 por ano! David Harvey alerta que a disputa pelo turismo engendra cidades rivais, cidades que se apresentam como criativas, onde o espetáculo é símbolo de seu dinamismo, apesar, no caso, deste Méditerranée não ser iniciativa de qualquer entidade baiana, mas de decisão métropolitaine.

Não considero honesto que a prática do turismo possa ser entendida fora do conjunto de práticas que constroem a vida das pessoas ao longo do tempo. Há longos matizes entre o eremitério e o mundo das representaçōes espetaculares. No primeiro, há isolamento, penitência, abstinência da carne, extrema penúria material, busca de Deus ou do sentido da vida, ampla consciência da transitoriedade do mundo material: o céu é o outro lugar, deve-se cuidar do mundo por ser obra da criação, mas sem excessos, porque não é o lugar definitivo. Mas hoje o frenesi no uso das delícias do ocidente é declarado, por todos segmentos sociais e espaços pós-queda do muro de Berlim. A angústia do homem, tão velha quanto os registros da tragédia grega, não encontra 
hoje, fora das filosofias religiosas, compensações da esterilidade das coisas e das agruras: a promessa do Éden foi substituída pelo consumo. E como já lembrou Baudrillard, o consumo pressupõe a manipulação ativa dos signos.

Por revés, ainda que corporificados pelas mais genuínas razōes do cotidiano das culturas, tudo indica que o rito e a busca do bonito de ser visto sempre estiveram presentes; claro que com significado muito diverso e particular a cada caso. Há vários e excelentes tratados sobre isto. Mas sinto falta de explanações que nos coloquem o peso que o "não essencial" deva ter no contexto de uma vida. A rigor, é teoricamente possivel viver sem exteriorizaçōes ditas supérfluas, ficando tudo reduzido às condiçōes espartanas de vida material. O mais clássico castigo familiar sempre foi pão e água, o suficiente para as crianças travessas não padecerem. Mas a verdade é que nem a vida monástica abre mão de seus rituais...

Por ocasião do Concílio Vaticano II, buscou-se abolir vários objetos e práticas religiosas que comprometiam o sentido evangélico e o plano de Deus. Supostamente, estatuária e estampas de santos; uso de batinas, hábitos, mantilhas e fitas; missas rezadas e cantadas em latim; conceitos de pecado; formas de jejum; papel da Virgem Maria e inúmeros outros itens deveriam assumir outro significado entre os fiéis católicos. É a mensagem que se lê em seus documentos Gaudium et Spes e Lumen Gentium. Decorridos 30 anos, a Igreja Católica do Ocidente acha-se completamente modificada, mas não em todos lugares e em todos segmentos sociais. Em princípio, objetos e aparências externas perderiam importância, diante do novo entendimento espistolar. Católicos então milenarmente habituados a santinhos e água benta, não aceitaram (e muitos até hoje) que de repente viesse uma nova ordem dizendo: De agora em diante essas bobagens externas não têm mais valor para Deus...

A Igreja se politiza, especialmente na América Latina. O resultado foi que a Renovação Carismática, antes limitada a pequenos grupos nos Estados Unidos, espalhou a reivindicação dos rituais pomposos junto com a religiosidade espiritual. A música ritmada e até mesmo a dança passaram a fazer parte de suas cerimônias, adequando-se a qualquer etnia. Seria muita ousadia etnocêntrica pretender que um grupo tribal de Gana ou Caribe, rezasse em latim, como papagaios, abandonando seus ritmos requebrantes. Ninguém abre mão dos rituais, desde os 
Eduardo

Yázigi

ortodoxos (ditos "os verdadeiros") em priscas eras. Mas do ponto de vista das Escrituras, pelo menos no Novo Testamento, não há qualquer preocupação exagerada com rituais, muitos dos quais, aliás, são tardiamente criados pelo cristianismo. Como explicar a encenação da Paixão de Cristo em Nova Jerusalém e os Círios de Nazaré em Belém do Pará? - espetáculos de expressão popular que vão se irradiando cada vez por mais cidades e, sustentados na religiosidade de multidões. Creio mesmo, que a encenação de uma festa como a do Divino, possa representar excelente trampolim para a criação de movimentos em defesa da cidadania e sua identidade. Não se esqueça que a maioria das ONGs americanas - o chamado capital social - nasceu justamente no seio de suas igrejas, após os ofícios religiosos.

O que dizer do budismo, graciosamente regado de flores e outras oferendas três vezes ao dia? E dos multicoloridos rituais hindus, sempre realizados com maquiagens, flores e danças nos templos espetaculares? E os rituais funerários balinenses e tantos outros? Estou falando de bilhões de pessoas! O ritual, como o turismo, é sempre fotogênico. Mas nem sempre e para todo mundo. As mesquitas muçulmanas situadas em regiōes muito freqüentadas por turistas, dividem seu espaço interno com uma severa corrente, no meio de cuja catenária pende uma placa advertindo: além deste ponto, apenas muçulmanos podem entrar... Nada mais justo e perfeito.

Para alguns autores (Crick: 65), quase todas as culturas são encenadas, - que leva John Urry (p. 25) afirmar que não fica claro que uma encenação destinada ao turista, aparentemente inautêntica, seja tão diferente daquilo que acontece de qualquer maneira em todas as culturas. Hoje em dia, raro turista ignora que são puras mise-en-scènes, o que certamente o leva a entendê-las como variados textos dramáticos, um jogo, enfim. Néstor Garcia Canclini (1973:107), de cujas boas interpretações me servi mais de uma vez, peca, no entanto, ao vincular a fantasia de um jardim, exclusivamente ao capitalismo: este, comenta ironicamente, precisa construir identidades imaginárias, fingir recordaçôes... os jardins do Hotel Princess são mais tropicais que a selva lexistem mais cocos, mais cipós, mais papagaios, há mais de tudo/... Na realidade, o que se tem, isso sim, parece ser antes um apropriação da fantasia e do espetáculo pelo capitalismo. Tomada que os exacerba e corrompe em tábula rasa. Aí a fantasia já vem sabiamente fabricada, porque chegou-se à sofisticação de pesquisar quais fantasias sensibilizam mais. Isto inicia um processo de jogo mais ou menos interativo,

\begin{tabular}{|l|l|lll|}
\hline 266 & $\begin{array}{l}\text { Paisagem } \\
\text { Ambiente } \\
\text { Ensaios } \\
12\end{array}$ & São Paulo n. 12 p. $253 \quad 287$ & dez. 1999 \\
\cline { 2 - 3 } & & & \\
\hline
\end{tabular}


consentido. $E$, por serem fabricadas, não realizam plenamente o papel que se costuma reservar; este só consegue sem completar com as construções situadas fora do jogo. Mas sob tais considerações, não me parece razoável forçar o descarte do papel histórico que cumpre na vida interior das pessoas. Há fantasias e fantasias, muitas delas não postas à venda. Parece-me que uma sedução espetacular só se torna perigosa quando integra o movimento manipulado que contribui para a imbecilização, como a psicologia de massas vem explicando tão bem. Aí sim, parece residir o verdadeiro perigo.

O Jardim do Éden (e não a "floresta" do Éden) de que fala a Bíblia situa-se no começo dos tempos e tem sua importância, mesmo como metáfora. Na Babilônia de Nabucodonossor, isto é, desde o século 7 a.C., seus célebres jardins suspensos foram considerados uma das sete maravilhas do mundo; mundo que teria de esperar mais de dois mil anos mais para conhecer o capitalismo. A proposta de jardins jamais foi a de igualar-se à natureza em estado puro, em todas as civilizações que os fabricaram. Muito pelo contrário. Ouando Burle Marx criou o Parque da Cidade (hoje deformado com pinus), não tinha como premissa recompor a flora natural do cerrado como seria "de verdade"... Do contrário nem os coqueiros poderiam fazer parte da paisagem brasileira, já que vêm da Índia. O tapete muçulmano é cheio de jardins e florais (ou fantasias geométricas), em contraste ao meio árido em que foi produzido. Em muitos países árabes, encravados em desertos, o jardim reproduz abundantemente, aquilo que thes é raro no meio circundante: daí a própria imagem poético-paradisíaca do oásis. Mais do que isso, a observação desses tapetes, produz sempre figuras de porções ocultadas pela moldura (o limite humano) que o homem não pode ver, por ser domínios de Deus (Maclagan: p. 32). Pela mesma razão não se deve tecer tapetes com a cor verde, reservada ao paraíso: eles são raramente fabricados. Jardim Zens ou ingleses (que trabalham o mistério dos jardins chineses) distanciam-se da flora natural para se converter em arte. $E$ arte pode se permitir de tudo em todos os tempos, inclusive brincar com rinocerontes...

Mais ainda, dado o caráter de ensaio que atribuo a este tema, ouso mesmo dizer que muitas exteriorizações estão na raiz da civilidade e, por conseqüência, da esfera pública e do pensamento democrático. Quando Erasmo de Roterdã publicou seu De Civilitate Morum Puerilium. há quase cinco séculos (com mais de 30 edições nos seis anos seguintes, enquanto ele ainda vivia), o que tinha em vista era o respeito pelo 
outro através da etiqueta. O autor regula a educação do príncipe discorrendo sobre o que é lícito ou não fazer à mesa: é o caso, por exemplo, da emissão de arrotos e outros sons originários do corpo... Mas ora, o desenvolvimento do capitalismo tal qual se vê hoje em dia, colando marcas registradas sobre sinais exteriores de beleza ou mesmo criando-as para a sedução exclusiva das vendas, denigri o sentido primeiro das coisas. É a forma pela forma. É o agrado só para vender e não por deferência ao outro. No conjunto, não é o espetáculo, propriamente, que estaria errado, mas a profanação de seu uso. Uso dos quais são cúmplices todos que, contraditoriamente, deixamse embebedar.

Nesta linha de raciocínio, vejo o espetáculo ou a fantasia a ele associada:

- no corpo e em sua imagem (na escolha das roupas; nos penteados; na maquiagem do branco ou do índio; na valorização estética do corpo; nas já antigas tatuagens; no uso de perfumes; nos trejeitos do andar e do porte em geral - e até nos animais que tiram partido de sua beleza para os mais diversos fins: a orquídea que banca a abelha-fêmea no ciclo da polinização; o pássaro com sua plumagem apelando ao acasalamento, etc.);

- nos rituais religiosos e de passagem (como exteriorizações de significado, do candomblé ao Vaticano, do nascimento à morte...);

- na etiqueta e nos protocolos (segundo variadíssima gama de exteriorizações, onde cada cultura estabelece seus códigos);

- na arquitetura e no urbanismo (nos monumentos; nos modismos; na permanência de estilos clássicos; na preocupação estética com a unidade e o conjunto urbano; na decoração de espaços públicos; na produção deliberada da ilusão ótica do tipo Parthenon ateniense, etc.):

- na decoração ou arquitetura de interiores /onde as salas de visita são destaque do preparo para os outros, onde até a não-decoração é uma auto-imagem);

- no paisagismo lque talvez não possa existir sem uma forte dose de mise-en-scène l;

- nas festas (no folclore; nas paradas militares; nas comemorações comuns; na velha tradição de decoração de comestiveis e coquetéis; no preparo dos ambientes; em todo aparato dos carnavais...); 


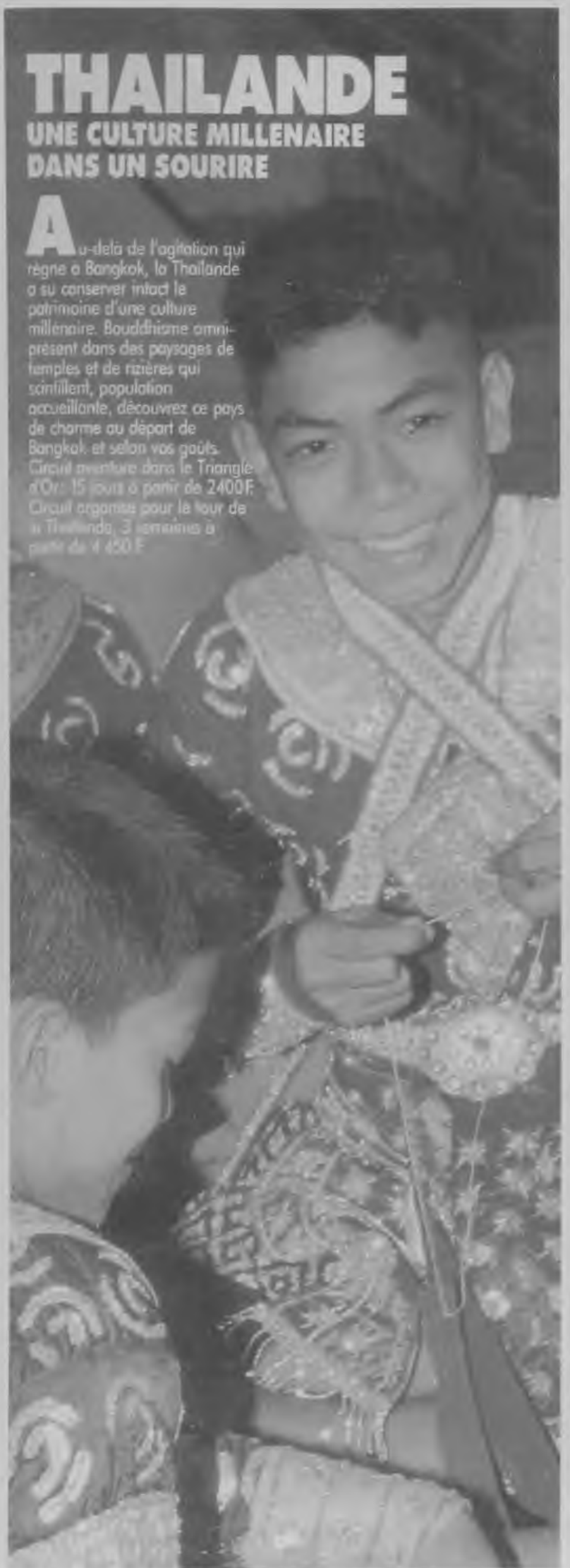

- nas artes cênicas e rítmicas (teatro; cinema; televisão; circo; pintura; escultura; música; dança - que é o refinamento dos movimentos, etc.|;

- na literatura de ficção e na poesia /onde a maioria dos gêneros não subsistem sem fantasia...);

- nas artes gráficas /desde os antigos papiros e iluminuras aos álbuns e cartéis cada vez mais esplendorosos):

- na realidade virtual lque vai passando dos computadores a várias esferas da vida cotidiana...);

- no design industrial (numa gama indescritivel de produções);

- nos esportes /de um crescendo criativo e deliberado de espetáculo em todas suas modalidades);

- etc., etc., etc.
Foto1: Nem os posters turísticos conseguem enganar totalmente. Aqui, se demonstra consciência da "agitação" de Bangkok, que seria melhor qualificada de "zorra" devido ao caos do trânsito, à poluição atmosférica e sonora insuportáveis. (Nouvelles Frontières, Catalogue 1990-1991: 61

Fonte: Cedida pelo autor 

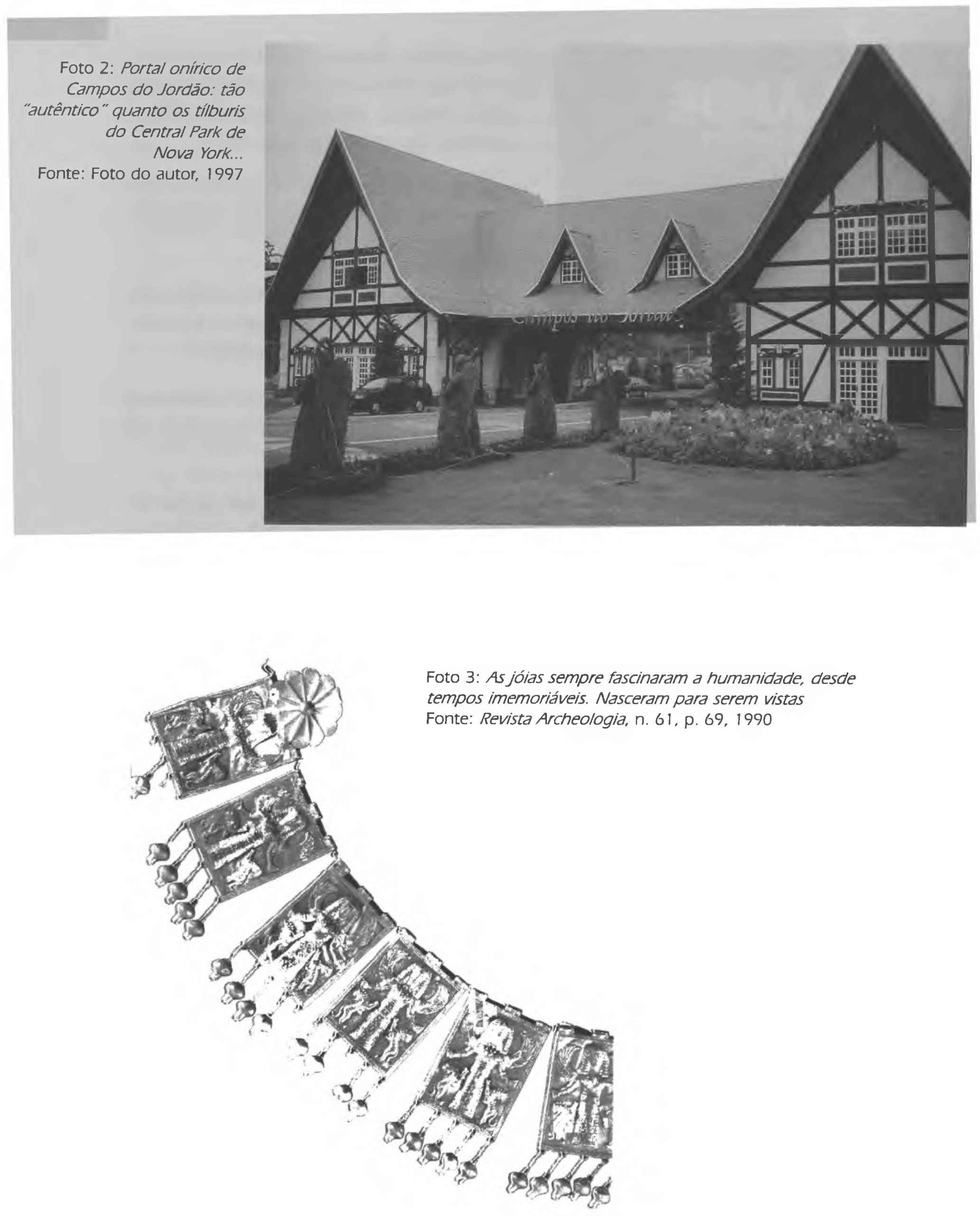

\begin{tabular}{|l|l|lll|}
\hline 270 & $\begin{array}{l}\text { Paisagem } \\
\text { Ambiente } \\
\text { Ensaios } \\
12\end{array}$ \\
\cline { 2 - 3 } & & \\
\end{tabular}




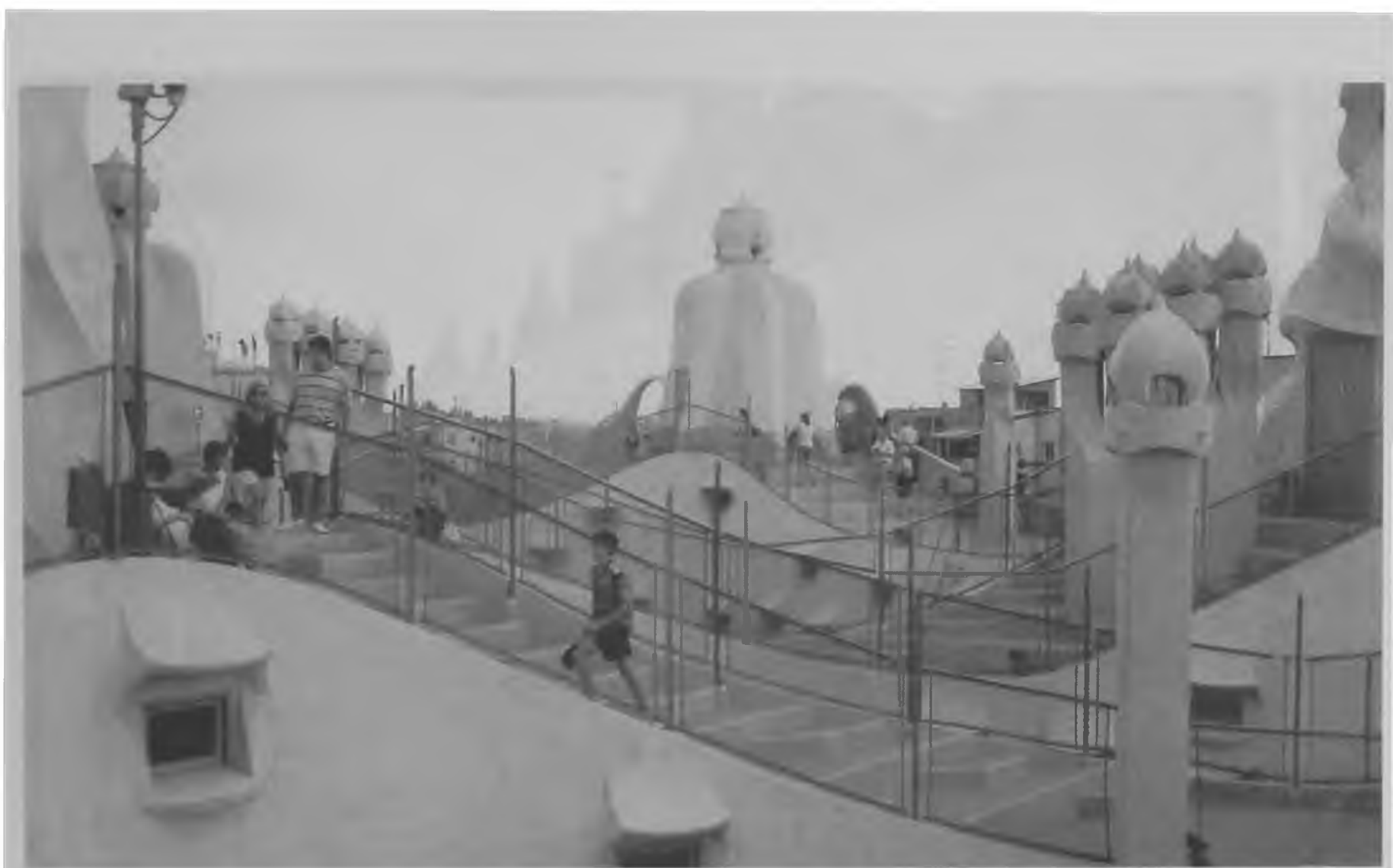

Foto 4: Arquitetura de Gaudi: Pode existir uma arquitetura de valor sem fantasia? (...) Fonte: SilvioSoares Macedo

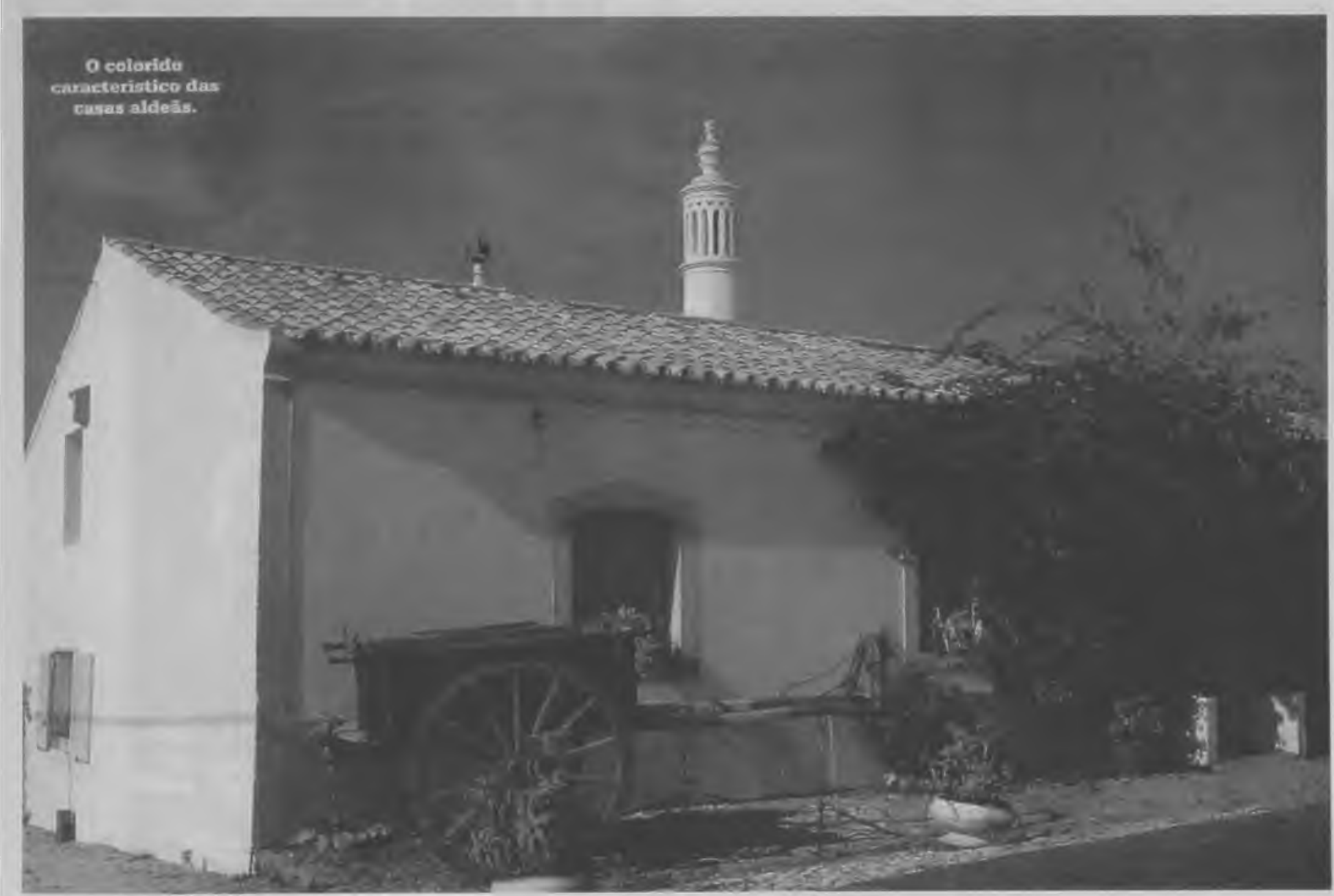

Foto 5: Casa portuguesa. Fantasias se revelam em interiores e fachadas Fonte: Revista Volta ao Mundo: 162 
Eduardo Yázigi
Devaneio e crítica

preliminares ao papel da fantasia na paisagem

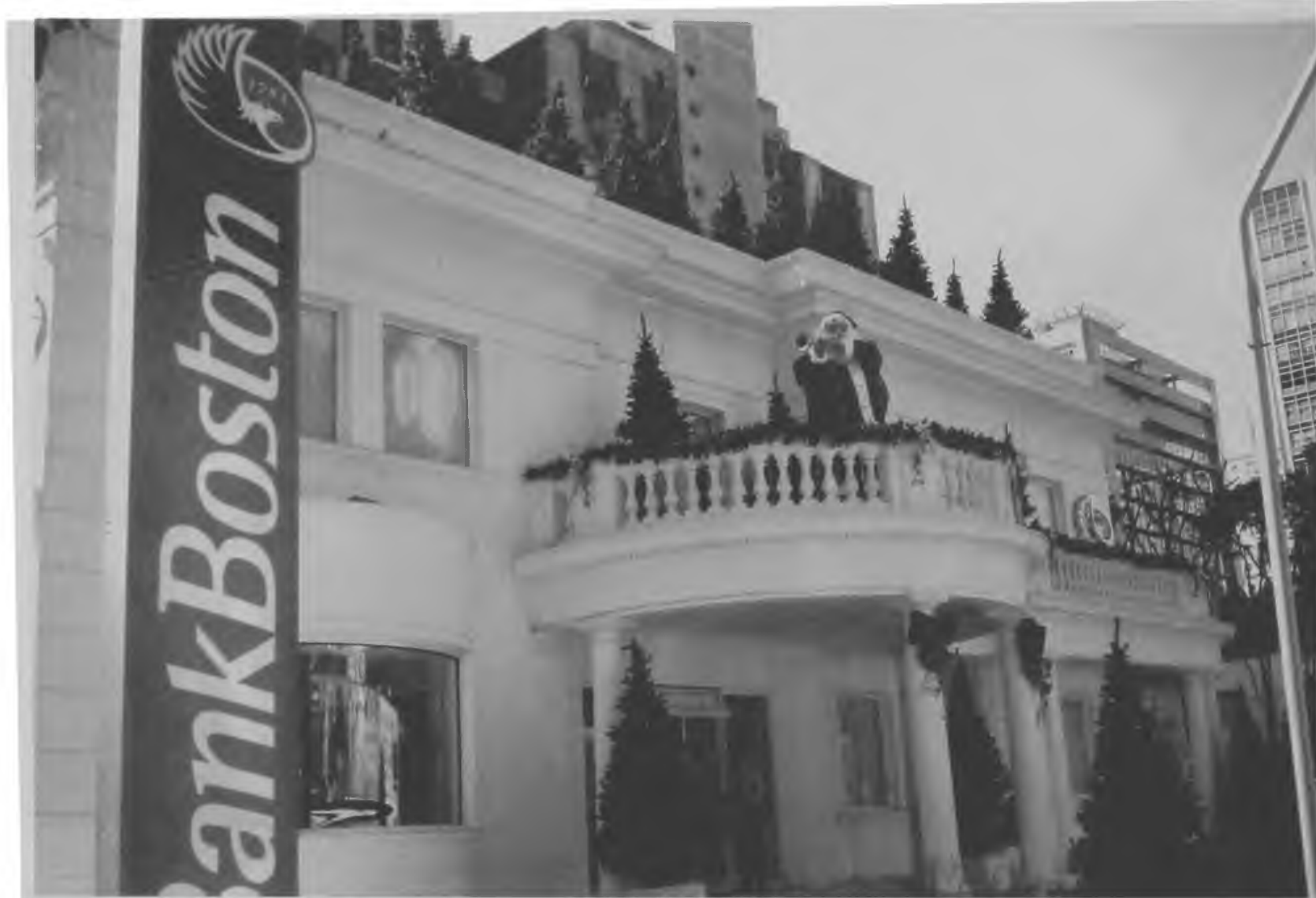

Foto 6: Decoraçâo de Natal. Este edifício da avenida Paulista já é uma fantasia, encimada por outra.. Fonte: Foto do autor, 1998

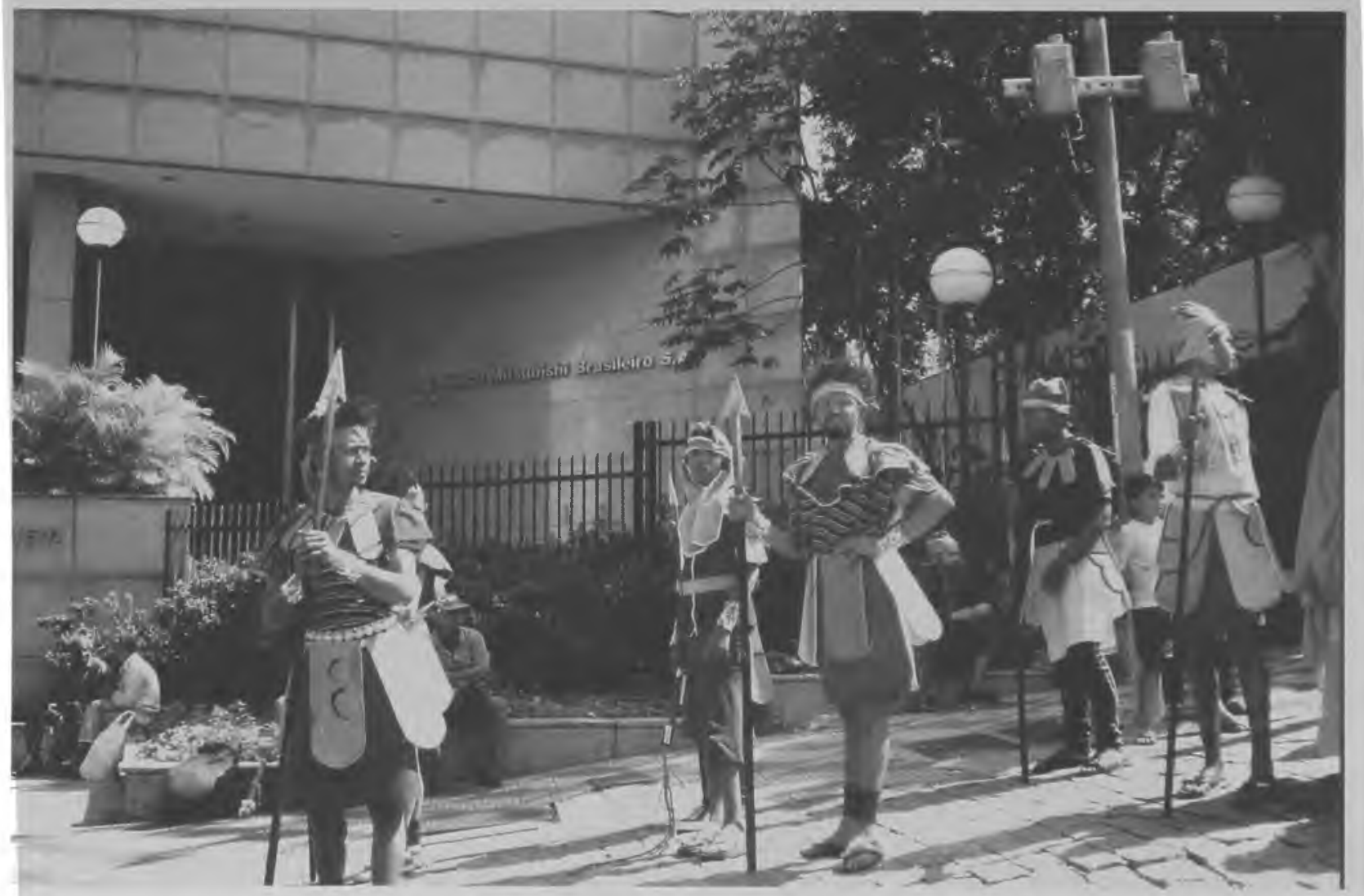

Foto 7: Encenação-espetáculo da Semana Santa, pelos povos da rua, para fins de sensibilização Fonte: Foto do autor. Rua Líbero Badaró, Sāo Paulo, 1996 


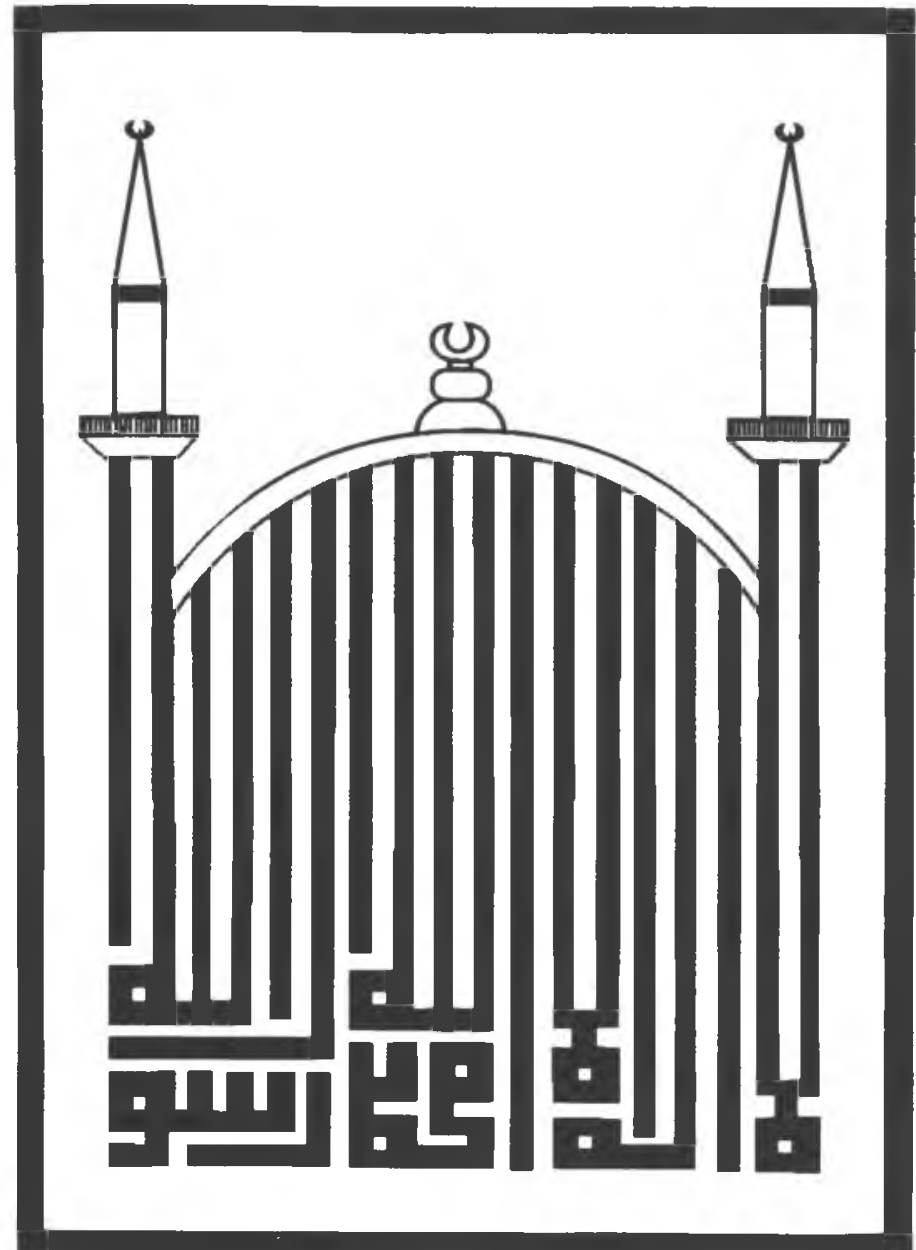

Figura 8: A velha caligrafia árabe é célebre por seus arabescos fantasiosos. Tradução: "Só existe um Deus e Maomé é seu enviado"

Fonte: Cedida pelo autor

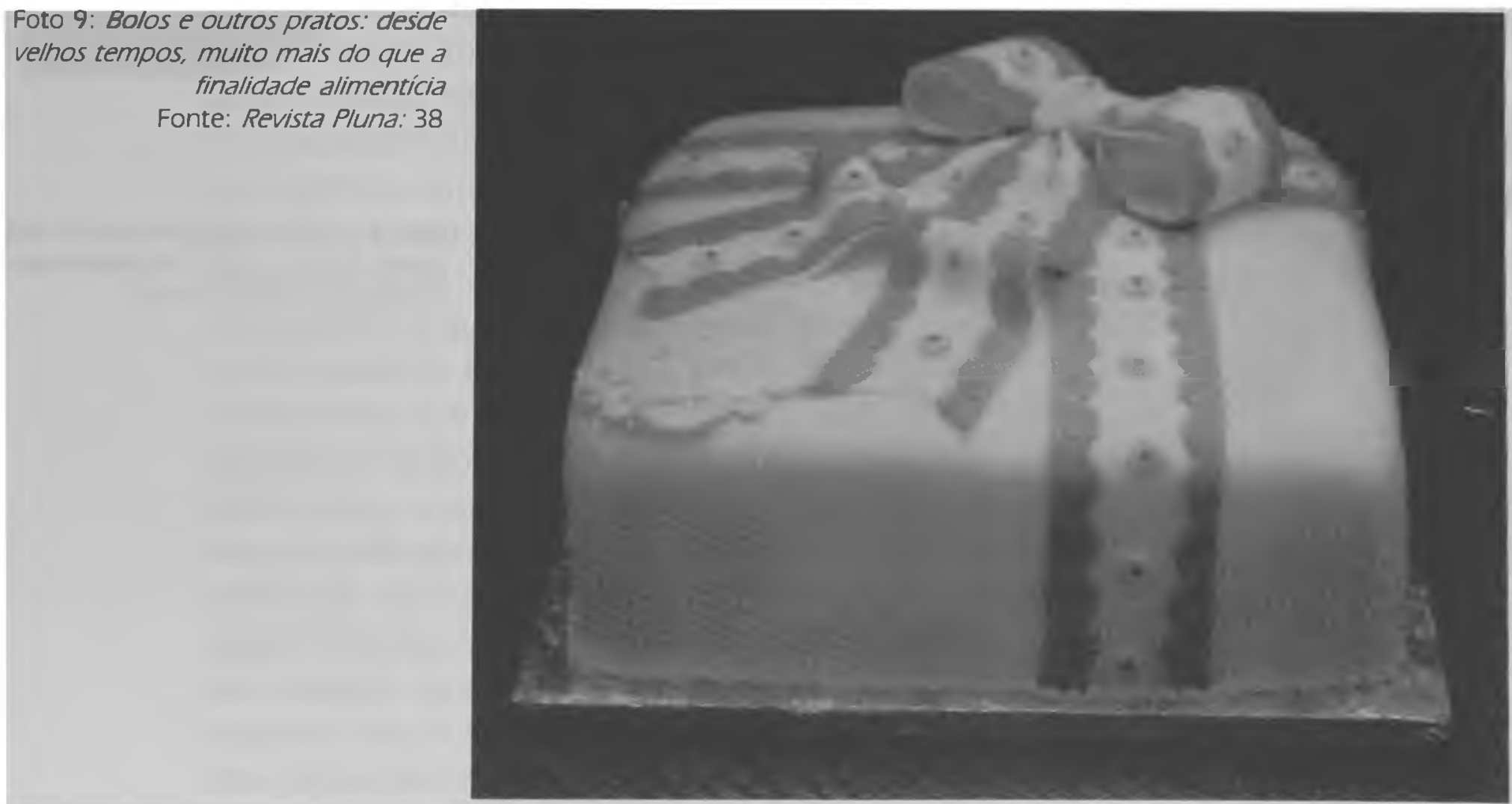




\section{Eduardo \\ Yázigi}

Devaneio e crítica

preliminares ao papel da fantasia na paisagem

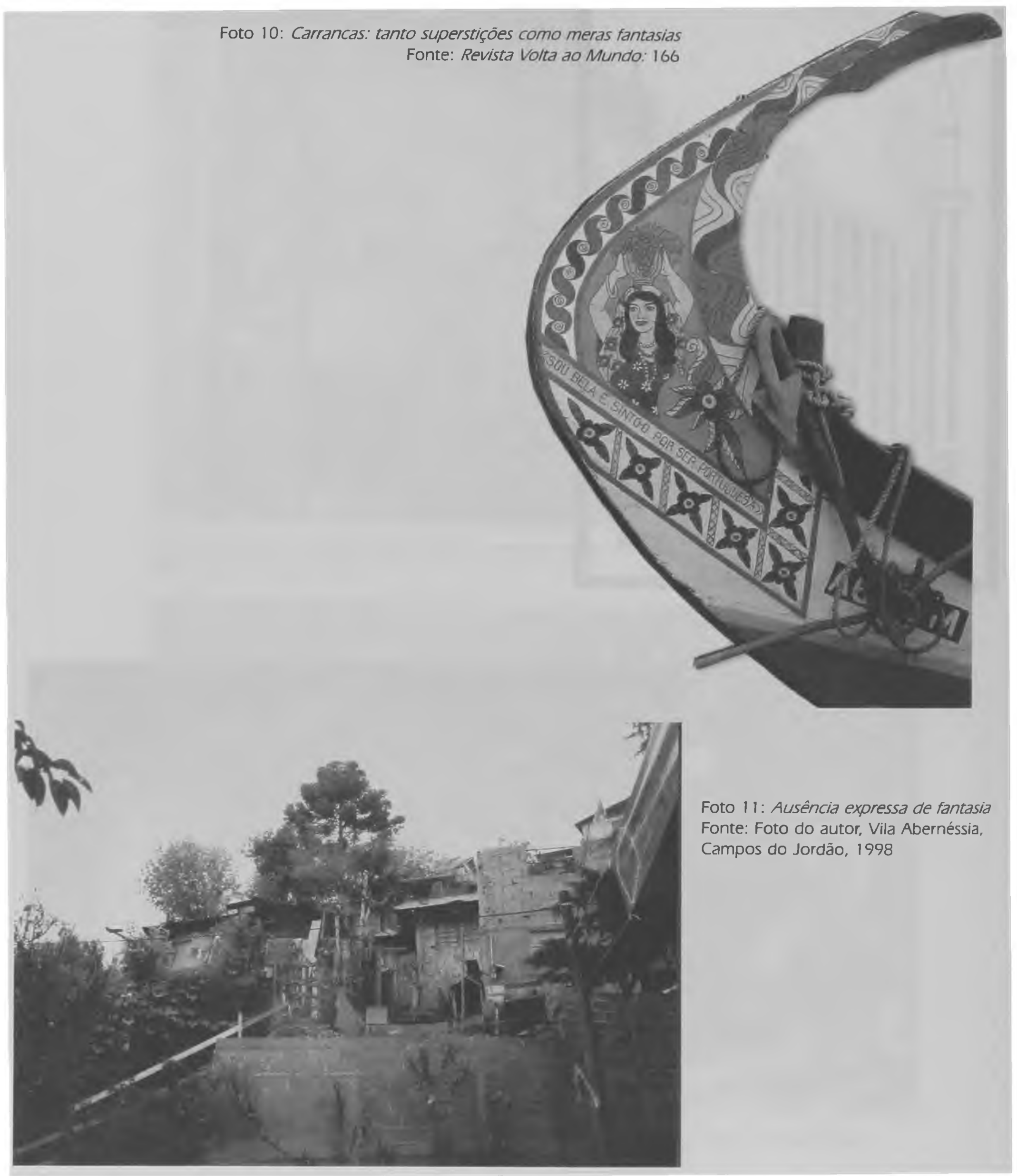




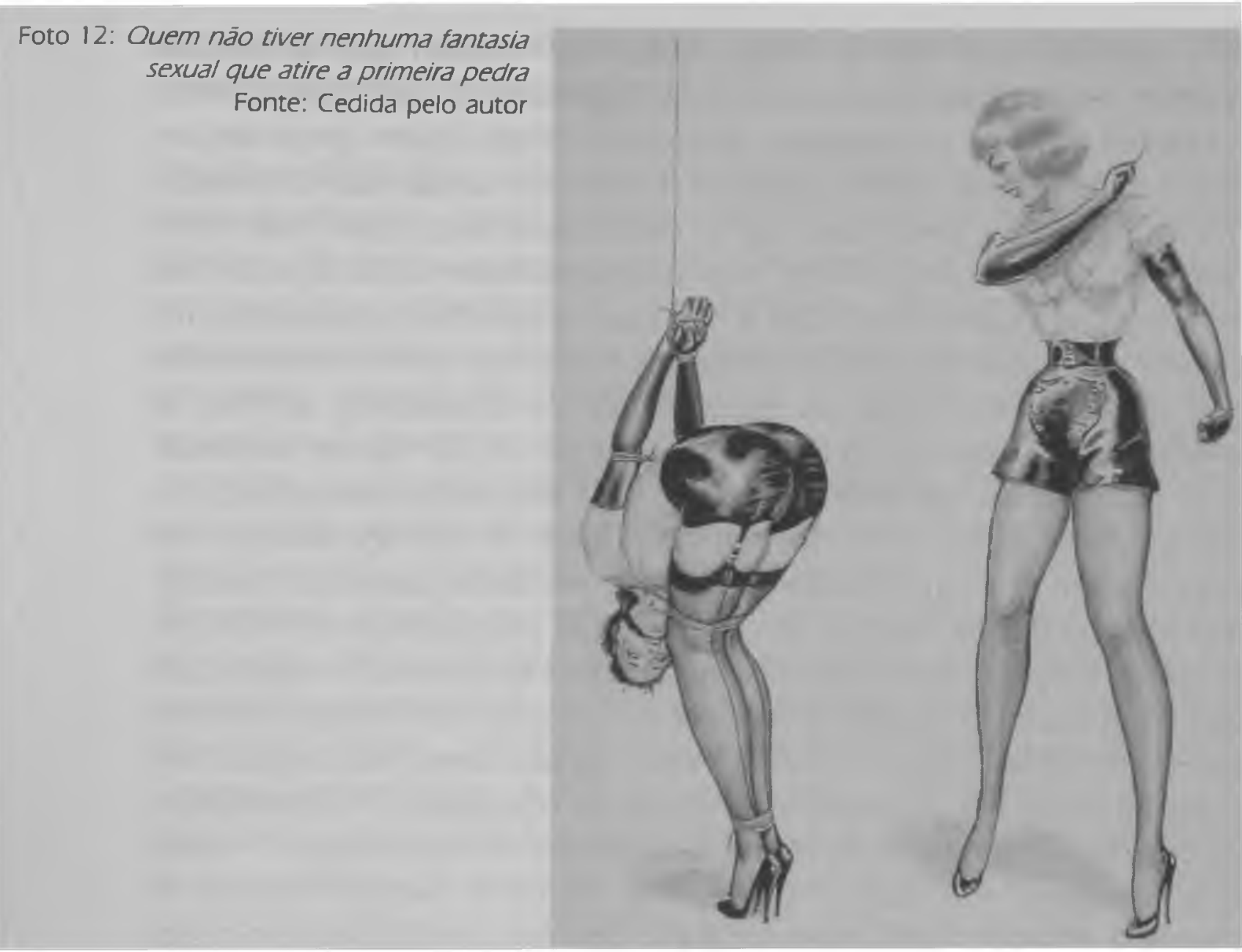

São apenas alguns exemplos de produçōes reais e mentais, desde o princípio dos tempos, para serem vistas; as funções são as mais variadas possíveis, mas raramente se abre mão de uma certa mise-enscène. Senão, qualquer chita ou bloco de cimento bastariam para todo mundo fazer casa e roupa. A auto-representação e a representação cósmica sempre existiram. Há um conhecido caso na antropologia, da esquimó que se exilou voluntariamente num recanto afastado da aridez polar. Anos depois, quando foram ver se ela ainda estava viva, supôs-se que teria fabricado apenas os utensílios indispensáveis à sobrevivência no frio glacial, mas qual não foi a surpresa, quando se descobriu que tinha produzido grande série de coisas inúteis, como escultura e baixos relevos em instrumentos de ossos de foca. Ao que tudo indica, o adorno era muito mais corrente em velhos tempos do que em civilizações industriais e capitalistas. Nessas aliás, o desejo do lucro fácil, colocado em primeiro plano, não pode perder tempo com essas minúcias que tanto deleitam as pessoas comuns. Cito apenas um, Barbara Jones (1951), entre tantos autores que mostram a preocupaçāo com o adorno (de carrancas a bolos de aniversário), até nas ditas artes não sofisticadas. 
Sim, pode-se viver com o frugal... Mas não é assim que as pessoas querem, salvo os teóricos (que não raro apreciam os melhores vinhos). A célebre frase do carnavalesco Joãozinho Trinta lquem gosta de pobreza é intelectual, pobre gosta de muito luxol ainda não foi devidamente refletida a sério: será que o deslumbramento (com mais forte razão no povol com o brilho, não será justamente uma fuga de seu cotidiano desguarnecido? Não é isso que os aportes da psicologia revelam? Uma grande pesquisa realizada em favelas do Rio demonstrou que os chamados marginais operários tinham os mesmos sonhos, as mesmas aspiraçôes que o resto da população e que não se interessavam pela cultura operária imaginada para eles pelos intelectuais, comenta Joffre Dumazedier (p. 42). Que falar de Mickey Mouse, um personagem que tem fã clube de adultos, em várias partes do mundo, inclusive no Brasil? No país do carnaval, que exige penca de meses de ensaio e preparo, tudo foi reinventado para o turismo: o espetáculo leva as massas ao transe. A arquitetura popular dos tempos do café revela modestas casas ou sobradinhos, dando direto na calçada, em cujas fachadas era quase norma moldarem colunatas em substituição às colunas. Colunas de mármore precisavam de mais espaço e eram coisa de gente rica, como nos casarões da velha avenida Paulista. A colunata, então, era uma pseudocoluna, uma fatia longitudinal em gesso ou cimento, uma fantasia possível...

\section{(O) reverso do postal}

A viagem tem sido apontada pelos teóricos como a busca do diferente, a fuga do cotidiano, em favor do exótico. Mas como bem assinala Lucrécia d'Aléssio Ferrara (In: Yázigi et al: p. 15 sqq) turista e viajante não são a mesma coisa. Pergunto-me mesmo se os primeiros grupos de homo sapiens não tinham uma dose de saber o que há atrás da montanha, na virada do rio ou do outro lado do mar; se isto também não contou em sua expansão mundo afora. Soa estranho admitir superpopulação em jurássicos tempos. Os psicólogos e teóricos em heurística, até zoólogos que fazem experimentação com ratos são unânimes: a curiosidade é parte indissociável da psique humana. Hoje pelo menos, fuga, busca do diferente e de aventura seriam ingredientes motivadores do turismo, tanto quanto questões existenciais não resolvidas. Não me parece que se pos-

\begin{tabular}{|l|l|lll|}
\hline 276 & $\begin{array}{l}\text { Paisagem } \\
\text { Ambiente } \\
\text { Ensaios } \\
12\end{array}$ & São Paulo n. 12 p. $253 \quad 287$ dez. 1999 \\
\cline { 2 - 3 } & & & \\
\hline
\end{tabular}


sa questionar o modo como as pessoas praticam o turismo, sem considerar também seus aspectos sociais.

Dito de outra forma, não se pode culpar somente o espetáculo - que tem sua recíproca. Salvo pessoas que têm medo de viajar, ou muito carentes de meios, apenas grupos solidamente voltados para uma vida interior e, arraigados em seu cotidiano, encontram satisfações sem necessidade de viagens e fantasias externas. Pode-se mesmo perguntar: a que ficaria reduzida a vida das pessoas, se privada desses lenitivos? Atuaremos nos efeitos ou nas causas? Quem (ou o quê) responde pelo preenchimento de suas vidas fora da produção? Em toda história da televisão brasileira, jamais os animadores com auditório foram de uma baixeza tão asquerosa como neste fim de século. No entanto, são eles e as emissoras os unicos que a crítica culpabiliza, ignorando olimpicamente que são ovacionados por milhões de espectadores, com índices recordes de audiência. Pega maldizer que o povo está errado... Do mesmo modo, a música alta em quase todos lugares, convertida em ruído, em antimantra mesmo, permanece resguardada porque não fica bem falar mal de música, mesmo como sucata sonora. Em suma, o deleite dos olhos (para o consumo ou nãol é condenável; o dos ouvidos (para o consumo ou não) não o é, apesar de afetar a própria saúde...

Por conseqüência de minha formação e convicções, pregaria o recoIhimento, o silêncio, a sobriedade e o franco encontro. Não sou entusiasta de festas, mas tenho de reconhecer a motivação dos outros. Os teóricos insistem na primazia do encontro sobre o espetáculo. Nunca antes o encontro foi tão favorecido e, às vezes penso que o brasileiro não faz outra coisa de seu tempo livre senão encontrar-se o tempo todo. Isto fascina qualquer estrangeiro. Já comunicação é outra coisa. Mas aí estão telefone, fax, celulares (com o Brasil entre os campeões da modalidade), bips, telefones comunitários ou de aluguel, ao alcance até de quem vive com bem pouco. Aí estão os transportes regionais cada vez mais fáceis, rápidos e baratos, as associações, sindicatos, paróquias, asilos, creches, escolas, clubes sociais, competições desportivas, atividades culturais até em periferia, centenas de lugares de encontro em cidades maiores que têm cinema, escolas, teatro, estádios, centros de convenção... Mas absolutamente, não creio que seja sob o clima de "eterno carnaval" subtraindo cada vez mais tempo de trabalho social, que gravíssimos problemas nacionais e mundiais possam ser resolvidos. 
Aqui entramos num lance perigoso desta narrativa, no sentido de que pode parecer que estaríamos sugerindo encantamento. É justamente aí que entra a psicologia. A psicologia social, em especial, teria algo a nos dizer. Seria preciso entender o fenômeno da encenação mais dialeticamente. De um lado, os interesses do capital produzindo a espetacularização da cultura, de outro lado, a população abraçando-a na falta de opções diferentes de psiquismo e vida. Ora, o consumo do espetáculo turístico é feito por turistas. Mas a regra é que ninguém é turista o tempo todo. As atribulações do mundo moderno, que não poupam até habitantes de cidades pequenas, têm de encontrar lenitivos que permitam, através do lazer por exemplo, recarregar as pilhas que os movem. O sonho da civilização do lazer está até nos textos de Lenin e Trotsky na justificaçāo do comunismo. O grande problema é que o espetáculo está invadindo todos os setores da vida o tempo todo: quase não há mais ambientes (comércios, serviços, e agora até espaços públicos) sem música em volume exagerado. As vitrines se rivalizam em sedução... Os princípios da Disneyworld são copiados em parques temáticos do mundo todo e até em museus, talvez porque tente ser uma versão tridimensional e animada do conto de fada, mas colocado à venda... Paira um horror generalizado ao silêncio e aos sons naturais. $O$ que falar então da prática desportiva, que não aceita mais a mera função original de educação do corpo, para se tornar, inquestionavelmente, algo para ser visto e de forma espetacular? E o surgimento da realidade virtual? E ninguém inclui isso na crítica à espetacularização! Vã foi a guerra de Georges Duhamel (1884-1966) contra o lixo sonoro, durante largo tempo.

Não me aparece apropriado aos epistemólogos do turismo ou da semiótica dizer de que jeito os homens devem ser psiquicamente felizes, mas deve fazer parte de suas preocupaçōes entender o papel do fenômeno da sedução enquanto organizador ou desorganizador da vida. Mesmo reconhecendo-se o papel da fantasia, paira o perigo do cenário pelo cenário, perceptível quando o homem vira ator manipulado e abandona a busca do eu com o universo. Como planejadores, proporcionar um quadro de vida capaz de cumprir sua parte da melhor forma possível para toda sociedade. Se formos capazes, apontar soluções alternativas, que se reconheçam as reais necessidades do outro, a serem incorporadas num novo modelo civilizatório. Em que campos estarão as novas referências?

\begin{tabular}{|l|l|lll|}
\hline 278 & $\begin{array}{l}\text { Paisagem } \\
\text { Ambiente } \\
\text { Ensaios } \\
12\end{array}$ & São Paulo n. 12 p. $253 \quad 287$ & dez. 1999 \\
\cline { 2 - 3 } & & & \\
\hline
\end{tabular}


A sociedade moderna está, igualmente, ressuscitando ou inventando tradições sob forma de espetáculo, pois o lugar turístico vive e cobra muito o "típico" Aqui se faz necessária uma distinção entre tradição e costumes das sociedades tradicionais. Na tradição, real ou inventada, há forte dose de invariabilidade, enquanto que o costume não pode evitar a mudança, porque a vida é assim, mesmo nas sociedades tradicionais. Por isto, Hobsbawm ( $\rho$. 17) as classifica em três categorias superpostas: a) aquelas que simbolizam a coesão social ou as condições de admissão de um grupo ou de comunidades reais ou artificiais; b) aquelas que estabelecem ou legitimam instituições, status ou relações de autoridade; e, c) aquelas cujo propósito inicial é a socialização, a inculcação de ideais, sistemas de valores e padrōes de comportamento. Vários autores apresentam longas listas de tradiçōes inventadas, deliberadamente, hoje tidas como legítimas. As organizaçōes direta ou indiretamente ligadas ao mercado, criam as suas em função do lucro que representam. Aí o turista dá vazão à nostalgia e ao seu tipo de comprometimento com a história...

A nostalgia vem marcando a música, moda, literatura, cinema, teatro, arquitetura... De acordo com boas interpretações históricas e psicológicas, ela tem mais a ver com os pensamentos passados do que com os fatos reais. É um sintoma de mal-estar provocado por perturbaçōes presentes, que trincam identidades e se resolvem por escapes (Lowenthal: 13): do passado, que é parte de nossas identidades, tendemos a isolar apenas as coisas boas que nos compensam. Socialmente, isso tem exemplos alegóricos no turismo. Quando este fenômeno assume feições de ruralidade, a fazenda é sempre a construção idealizada, cheirando bolo de fubá e café, com uma cozinheira maternal, preta e gorda de preferência, com ambiente anti-séptico, sem os instrumentos de trabalho ou tortura, e sobretudo, sem a "detestável" presença de fantasmas de escravos urrando, bóias-frias e sem-terras... A tradição da fazenda é uma história inventada. John Urry cita que $56 \%$ dos novos museus britânicos são particulares e fazem do passado uma mercadoria. O perigo é que esse tipo de construçāo do passado mascara a fragmentação do presente com suas discrepâncias sociais e espaciais.

O Brasil não permanece isento de inventar tradiçōes. As populares festas do Halloween ou do Havaí, absolutamente estranhas ao Brasil até início dos anos 70, tornam-se parte do calendário de incontáveis cidades. A Oktoberfest, realizada pela primeira vez para celebrar a cura de 
uma princesa alemã, associada ao quadro pará-germânico de Blumenau, traz, anualmente, um milhão de turistas... Até cidades sem passado alemão tentaram imitá-la. Uma tal fábrica de panetone, não contente com as vendas de Natal, vem anunciando em out-doors o bolo Colomba Pascal, ostensivamente declarado a nova tradição da Páscoa... Já se viu a tentativa frustrada de criar um carnaval baiano em pleno mês de julho, quando turistas estariam disponíveis...

Mas no Rio Grande do Sul, estado mais orgulhoso de suas tradições, há tanto festas genuínas, como tradições recém-inventadas. Os famosos CGTs - Centro de Tradições Gaúchas - são locais cultivadores de eventos, antes de mais nada para orgulho dos próprios gaúchos. Existem em todas as cidades do Rio Grande do Sul e onde houver alguma concentração e emigrantes gaúchos: Santa Catarina, Mato Grosso, Rondônia... Abrigam festas privadas e públicas, sempre com música gauchesca, dança, churrasco e chimarrão. Já as Cavalgadas do Mar, são recente criação de João José Machado, fazendeiro do litoral e bacharel em direito, imaginada para celebrar o sesquicentenário da Revolução Farroupilha, em 1985, (de caráter separatista), o que reforça a busca sul riograndense de identidade. Eram 13 cavaleiros que saíam de Palmares do Sul, $200 \mathrm{~km}$ pelo litoral abaixo. Em 1990 já eram 500. Conforme um de seus organizadores, "O Rio Grande, no verão, se muda para o litoral... sem falar das pessoas que vêm do Uruguai e da Argentina aqui nas nossas praias. "São citaçōes da pesquisadora e escritora Elma Sant'Ana, em seu livro Os cavaleiros do mar. Segundo ela, o deputado Jarbas Lima remete para as expressōes Liberdade, Igualdade e Fraternidade, quando se refere a cavalgadas. "Estão escritas em nossa bandeira, mas precisam ser praticadas no dia-a-dia da sociedade riograndense"... (p. 23).

A cavalgada chega a ser um belo espetáculo, ainda que menos reluzente que a célebre “Fantasia” do Marrocos. Já os CGTs têm o grande mérito de serem feitos para eles mesmos, pelo menos na maior parte das unidades, por enquanto. Acontecem em lugares em que ninguém sonha fazer turismo. Alguém que não tenha ligações com parceiros gaúchos, dificilmente busca um CGT, no repertório de suas andanças. As milhares de missas católicas, a cada dia no mundo, não atraem turistas, mas os cantos gregorianos (e a entrada sempre teatral dos monges no altar) têm chamado multidōes de visitantes e até dificultado as próprias celebrações no Mosteiro de São Bento de São Paulo, depois

\begin{tabular}{|l|l|lll|}
\hline 280 & $\begin{array}{l}\text { Paisagem } \\
\text { Ambiente } \\
\text { Ensaios } \\
12\end{array}$ & São Paulo n. 12 p. $253 \quad 287$ dez. 1999 \\
\cline { 2 - 3 } & & & \\
\hline
\end{tabular}


que foi anunciada no roteiro turístico pelas mídias. Condená-los não seria uma forma de intelectualismo farisaico? Será puro espetáculo ou há pessoas que tiram bom partido, mesmo que en passant? Não seria leviano demais condená-los em oposição a outros ("os genuínos") que apreciam o mesmo tipo de canto?

A cavalgada de gaúchos seria a cultura entendida como parte da vida. para solução de problemas. Para o experimentado autor Hughes de Varine (p. 15), cultura é o conjunto de soluçôes encontradas pelo homem e pelo grupo face aos problemas que lhes são colocados pelo meio natural e social. Mas como bem alerta Mike Featherstone (1995: 134), mesmo inventado para fins mercantis, o espetáculo não se cria ex-nihilo, nem implica necessariamente em passividade do cidadão, que sempre renegocia seus símbolos. Secularmente, em casos de mordida por tarântula, a vítima siciliana devia agitar seu corpo e transpirar o veneno, daí surgindo a tarantela. Uma manifestação autêntica de como um fato cultural se constitui em solução às condições do meio, segundo as mais refinadas teorias da cultura. Mas quando a tarantela vira dança para turista?... Não estaria, neste caso, solucionando um problema de sustento? Num mundo onde desemprego é o pior dos fantasmas, fundamentados em quê, poderíamos desencorajar tal prática, seja ela tarantela, rock ou frevo? Neste caso, o problema primeiro a ser ponderado não é tanto o do espetáculo como o da sobrevivência.

No universo do mundo urbano brasileiro, o reverso do cartão postal tradicional não consegue despertar o menor interesse. A vida como ela é, aqui, onde o abismo social e a divisão territorial do trabalho vem sendo levados às últimas conseqüências pelo zoneamento, produzem cenários transparentes da organização espacial da vida. Logo, se a crítica ao espetáculo passar a se pautar pelo que é realmente representativo da sociedade brasileira, aí então, ao invés dos Corcovados ou igrejas barrocas, o trajeto teria de ser outro. No avesso da fantasia encontra-se o pesadelo suburbano, a nudez da arquitetura do desespero. São extensões de rara unidade paisagística onde moram classes médias: os mil bairros Olaria e Vilas-não-sei-o-quê que existem nesse Brasil. Se Los Angeles ou Miami conseguem motivar city tours para contemplação de suas ricas mansões, aqui nem isso: entre nós, os tediosos bairros ricos são os novos bunkers, as ruas estéreis, onde o fosso social é cavado no chão. Mesmo a distante Manaus, antes teoricamente protegida

\begin{tabular}{|l|l|l|}
\hline Săo Paulo n. 12 p. $253 \quad 287$ dez. 1999 & $\begin{array}{l}\text { Palsagem } \\
\text { Amblente } \\
\text { Ensalos } \\
12\end{array}$ \\
\hline
\end{tabular}


pelo cerco da floresta, vem difundindo de tal modo condomínios cercados por muros quilométricos, de ambos os lados da avenida, que torna o flanar de motivação zero. Em outras palavras, uma vez que se viu a floresta, só resta bater em retirada. Nem Poá, que é uma estância hidromineral, mas em posição de subúrbio paulistano, consegue atrair. Jamais ouvi falar de alguém que tivesse tirado férias por lá.

\section{F iglo veinte cambalache, problemático $y$ febril}

Imaginem se Camilo de Sitte, autor de $A$ construção das cidades segundo seus princípios artísticos, tivesse vivido hoje com aquele pensamento... Justamente, por congelar princípios supostamente universais, suas proposições são consideradas a-históricas; elas não prevêem o conflito, a mudança e o papel da tecnologia moderna. O mais curioso é notar como hoje em dia, grande quantidade de estudantes da arquitetura, do urbano e das áreas afins citam Camilo de Sitte como padrão a ser resgatado... A visão da cidade neste fim do milênio é tão desprovida de sentidos mais nobres que se recai na facilidade da nostalgia. Nostalgia que isola apenas os fatores positivos do passado, perdendo de vista todo o indesejável: os cortiços insalubres, os subúrbios fétidos e pestilentos por falta de saneamento, as jornadas infames impostas a mulheres, idosos e crianças, as torturas... Quero crer que "percepções" do passado, ainda que isoladas, alimentam o desejo de vida mais plena e elevada. Quem sabe, se cada casa e o trabalho tivessem um pouco do melhor dos mundos, inclusive psicologicamente, talvez se pudesse esperar uma diminuição da busca pelo lugar diferente, pelo fascínio do espetáculo e sua fantasia.

Visualizando os quadros da urbanização brasileira, é difícil discordar que está havendo um fabuloso culto ao feio em toda esfera espacial pública e em suas interfaces. O desleixo é generalizado. Em alguns casos por falta de recursos, competência, boa administração e disciplinamento codificado; em outros, pela absoluta falta de educação popular, pelo baixíssimo grau de exigência da esfera pública. As cidades fazem transbordar panoramas viscerais em seus bairros e subúrbios: construçōes de bloco ou de refugos, sem qualquer acabamento; total ausência de arborização; soluções arquitetonicamente

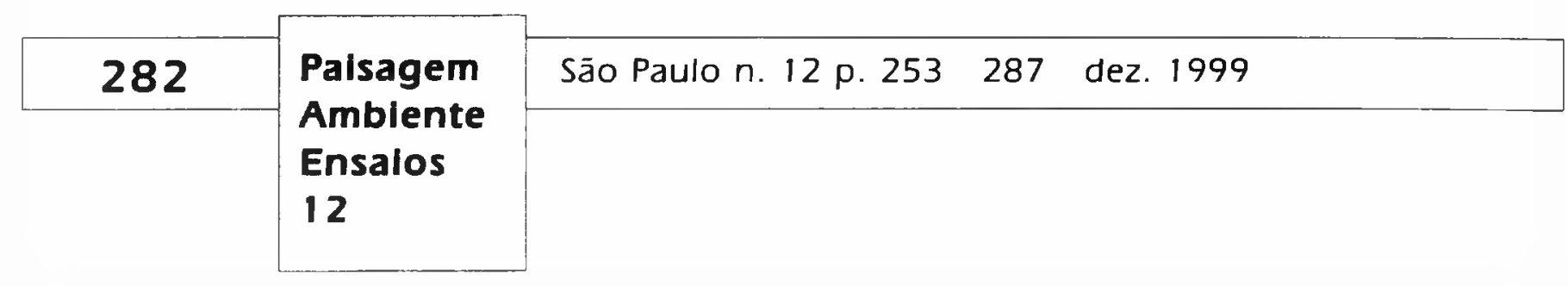


absurdas, sem a menor preocupação de vizinhança e conjunto; ruas lamacentas, esburacadas e sujas. Montões de gente no aviltamento das condições sanitárias infecciosas, cujo espaço público são riachosesgotos de lazer, imundos, onde crianças disputam lugar com ratos e baratas. São cenas familiaríssimas no cotidiano dos programas televisados, por causa das costumeiras catástrofes ou das açōes diárias da Polícia Militar - daí que ficamos anestesiados. O melhor dos piores bairros é indigno de uma viagem. Esta é a regra para a maioria. lemen, Portugal, Grécia, Tunísia, Jordânia e quantos outros da bacia mediterrânea mostram que a pobreza não precisa desembocar na degradação. Justamente quem mais precisa de um pouco de compensação, tem as mãos amarradas (e até contribui) para que seu cenário cotidiano seja desprovido e repelente. Por tudo isto perde-se para o turismo, mas sobretudo para o cotidiano. O Brasil não era assim, ele perdeu a graça, como diz Lígia Fagundes Telles.

O fenômeno da feiúra tem se manifestado até em países do classicismo e tem intrigado seus teóricos. Falar de beleza hoje lapós a Guerra do Golfol poderia parecer preciosismo, elitista, até fascista. As discussōes sobre beleza, durante muito tempo neste século, têm sido pervertidas pela apropriação totalitária do tema, tão freqüentemente negligenciado pelas preocupaçōes humanistas e existenciais com o desenvolvimento democrático... Se não abrirmos amplamente a questão, ela permanecerá não somente reprimida, mas, pior, sujeita a um mal uso totalitário... Pois, sejamos claros, o fascismo hoje não está onde estava há cinqüenta anos; nem está aqui em nossa disputa desse tema. Hoje, o totalitarismo está na televisão, em sua glorificação do equipamento de guerra, na tecnologia da destruição, na supressão do sentimento humano, com uma linguagem uniforme, e no patrimônio de massa agitado pelo derramamento de sangue... clama James Hillman (p. 129). Percebe a beleza como um tema reprimido, quando o que queremos é o mundo por sua beleza miraculosamente desdobrada - dos níveis subatômicos aos astronômicos. Resumindo, por baixo da crise ecológica está a crise mais profunda do amor: que nosso amor tenha abandonado o mundo, que o mundo esteja desamado, é o resultado direto da repressão da beleza, de sua beleza e de nossa sensibilidade para com ela. Para que o amor volte ao mundo, é preciso, primeiramente, que a beleza retorne, ou estaremos amando o mundo só como uma obrigação moral: limpá-lo, preservar sua natureza, explorá-la menos. (Idem: 131.) 
A preocupação contida no que foi ensaiado, consiste em saber se continuamos a alimentar os quadros de penúria e aridez (que são parte real da identidade, que se tornaram os mais fortes traços da personalidade do lugar) ou se buscamos reverter a situação, em vista da própria emancipação das comunidades, pela dignidade de seu cotidiano. A paisagem, como já se cansou de falar, é uma entidade que se transforma com o espaço, que se transforma com a história. O conhecimento deste Brasil e seus graves problemas pedem planos de desenvolvimento, soluções de fato, sem os quais a tentativa de criar um quadro de vida mais nobre seria outra fantasia. Não vejo como resolver o problema da paisagem brasileira, sem resolver a miséria, a miséria sem a justiça social e assim por diante. Projetos comprometidos antes de mais nada com o social, mas também com o patrimônio natural, com a estética e claro, sem negligenciar outros aspectos culturais valorativos do meio. E, sem demagogismos que corroem o cotidiano, aplaudindo qualquer zé-da-esquina só porque é zé. É quando artistas, arquitetos, urbanistas, paisagistas, psicólogos, cidadãos bem formados e associações ambientalistas têm de ser mobilizados contra a entronização da alienação ou dos horrores paisagísticos. Foi com o concurso dessa estirpe sonhadora que a humanidade produziu o que tem de melhor, até naquilo que sequer foi feito para ser monumento.

Como que à guisa de conclusão, diria que a reversão do espetáculo enquanto componente, em todas as instâncias da vida, não me parece viável fora do mergulho interior e a moldagem de outro tipo de civilização. Ela exige uma boa dose de transcendência, coisa que até hoje apenas ascetas e santos de todas as religiōes têm sido vanguarda. Esta viagem introspectiva, ou de casamento do eu com o universo, se preferirem, está totalmente fora de moda, pois não é com a leitura de trabalhos como este que as pessoas se deixam se convencer por outras plagas... A terra e a vida têm sido externamente assumidas como únicas e que portanto se trata de relaxar e gozar. Apenas as religiōes e filosofias conseguem contrapor valores que desdizem a figura de Narciso, a que melhor caracteriza nossos tempos: o tal que se apaixona por si mesmo. Supondo-se que a fantasia possa ser em parte compensada com um quadro de vida mais elevado, parece-me vão tentar resolver a questão pelo viés exclusivamente tópico: suas raízes são muito mais profundas e complexas. Nesta mesma ordem de idéias, penso que melhorar o cotidiano de vida das pessoas ajuda muito, não por "direito" de decidirmos sobre suas fantasias, mas porque seus lugares de vida são tristes. Pode-se morar numa mansão rodeada de jardins,

\begin{tabular}{|l|l|lll|}
\hline 284 & $\begin{array}{l}\text { Paisagem } \\
\text { Ambiente } \\
\text { Ensaios } \\
12\end{array}$ & São Paulo n. 12 p. $253 \quad 287$ dez. 1999 \\
\cline { 3 - 3 } & & & \\
\hline
\end{tabular}


mas sair à rua e ao cotidiano social se tornam viagens aviltantes. O grande senão da fantasia como problema para o planejamento se coloca quando ela interfere negativamente na esfera pública.

Mas como ninguém é turista o tempo todo, aos devaneios se intercalam a maioria dos meses, entremeado de rotinas e penas. Se o turismo merece reprovação, o que falar da esmagadora maioria de emissões televisivas espetaculares? O que falar da festa (e o que vai junto), sem qual o brasileiro já não consegue viver? Quem se atreve excluir o espetáculo do futebol? E a viagem do uso social do álcool? Como, por fim, ousar negar as fantasias sexuais inerentes ao homem? Por ninguém ter coragem de mexer de verdade nessas coisas, que estāo no mesmo tipo de escape? Atender à crítica, aos abusos discutidos, implica "apenas" em modificar os padrões de prazer, o que equivale dizer: modificar o psiquismo, o modelo civilizatório e político... Há mais de 50 anos, William Reich, em a $A$ função do orgasmo - dizendo respeito tão somente à questão sexual - demonstrou os vínculos entre o gozo e a democracia. Isto é um lembrete para que não se caia na simplicidade de proposições desvinculadas da complexidade que a questão abarca. Poderia ter acrescentado um subtítulo a este ensaio, que ficaria assim: Devaneio e crítica - ou a angústia existencial. Você decide.

Se o cidadão carece de fantasia, não cabe ao Estado alimentá-la, mas proporcionar o melhor para a fluência da vida cotidiana. Sua regulação teria de corresponder ao que se espera da esfera pública, inviável de ser equacionada, sem suas interfaces com o privado - isto é, com o ajuste consciente do grupo social a que se refere. Uma discussão já tardia, e que tem de ser iniciada no âmbito do planejamento. Sem isto afrouxa-se ainda mais a possibilidade de controle do território enquanto paisagem, reveladora de uma identidade em reconstrução, para a riqueza do cotidiano e do turismo.

\section{$B / B L / O G \mathbb{A} F / A$}

ARISTÓTELES. De I'Ame. (Traduction nouvelle et notes par J. Tricot). Paris: Librairie Philosophique J. Vrin, 1959

BACHELARD, Gaston. La poética del espacio. México: FCE, 1993.

El derecho de soñar. México: FCE, 1993.

BAUDRILLARD, Jean. Le système des objets. Paris: Gallimard, 1968.

BEVERIDGE, W. I. B. Seeds of discovery. Londres: Heinemann Educational Books, 1980 
CANCLINI, Néstor García. As culturas populares no capitalismo. São Paulo: Editora Brasiliense. 1973.

CRICK, M. Sun, sex, sights, savings and servility. Criticism, heresy and interpretation, n. 1, p. 37 76,1988

DE BONNO, Edward. O pensamento criativo. Petrópolis: Vozes, 1970.

DUMAZEDIER, Joffre. A revolução cultural do tempo livre. São Paulo: Studio Nobel-Sesc, 1994.

ECO, Umberto. Viagem na irrealidade cotidiana. Rio de Janeiro: Nova Fronteira, 1984.

FEATHERSTONE, Mike. Cultura global. Petrópolis: Vozes, 1994. 1995.

O desmanche da cultura. Globalizaçāo, pós-modernismo e identidade. São Paulo: Nobel,

FERRARA, Lucrécia d'Aléssio. O turismo dos deslocamentos virtuais. In: YÁZIGl, Eduardo et al. Turismo: espaço, paisagem e cultura. São Paulo: Hucitec, 1995.

FREUD, Sigmund. The relation of the poet do day-dreaming. Collected Papers. Londres: Hogarth, 1908, v. 4, p. 173-183 (Originalmente publicado com o título Der Dichter und das Phantasieren.l

Creative writers and day-dreaming. The standart edition of the complete works psychological works of Sigmund Freud. Londres: Hogarth, 1953-74.

HARVEY, David. Do gerenciamento ao empresariamento: a transformação da administração urbana no capitalismo tardio. Espaço e Debates, n. 39.

HILLMAN, James. Cidade \& alma. São Paulo: Nobel, 1993.

HOBSBAWN, Eric, RANGER, Terence (org.). A invenção das tradiçōes. Rio de Janeiro: Paz e Terra, 1997.

JONES, Barbara. The unsophisticated arts drawns and described by Barbara Jones. Londres: The Architectural Press, Staples Printers Limited, 1951

KOESTLER, Arthur. The act of creation. A study of conscious and unconscious in science and art. Nova York: A Laurel Edition, 1967.

LOWENTHAL, David. The past is a foreign country. Cambridge: Cambridge University Press, 1990.

MACLAGAN, David. Creation myths: man's introduction to the world. Singapore: Thames and Hudson, 1979.

MALFÉ, Ricardo. Fantásmata. El vector imaginario de procesos e instituciones sociales. Buenos Aires: Amorrotu Editores, 1995.

MENESES, UIpiano Toledo Bezerra de. Os 'usos culturais' da cultura. In: YÁZIGI, Eduardo et al. Turismo: espaço, paisagem e cultura. São Paulo: Hucitec, 1995.

MORIN, Edgar. La méthode: la conaissance de la connaissance. Paris: Seuil, 1986.

PERSON, Ethel. O poder da fantasia: como construimos nossas vidas. Rio de Janeiro: Rocco, 1997.

RAPAPORT, David (Dir.). Organization and pathology of thoughts: selected sources. Austen Riggs Foundation, Monograph, n. I. Nova York, Columbia University Presses, 1956

SANT'ANA, Elma, STOLARUCK, André. Os cavaleiros do mar. Porto Alegre: Editora Age Ltda., 1990.

\begin{tabular}{|l|l|l|l|l|}
\hline 286 & $\begin{array}{l}\text { Paisagem } \\
\text { Ambiente } \\
\text { Ensaios } \\
12\end{array}$ \\
\cline { 2 - 3 } & & \\
\hline
\end{tabular}


SANTOS, Milton. Técnica, espaço, tempo, globalizaçāo e meio técnico-científico informacional. Sāo Paulo: Hucitec, 1994.

SOUZA, Octavio. Fantasia de Brasil. As identificaçōes na busca da identidade nacional. São Paulo: Editora Escuta, 1994.

STORT, Eliana V. R. Cultura, imaginação e conhecimento: a educaçāo e a formalizaçāo da experiência. Campinas: Editora da Unicamp, 1993.

SZILASI, Wilhelm. Fantasía y conocimiento. Buenos Aires: Amorrotu Editores, 1977

URRY, John. O olhar do turista. São Paulo: Nobel, 1996.

VARINE, Hughes de. La culture des autres. Paris: Seuil, 1976. 